Prepared in cooperation with the Pennsylvania Department of Health and the Pennsylvania Department of Environmental Protection

\title{
Evaluation of Radon Occurrence in Groundwater from 16 Geologic Units in Pennsylvania, 1986-2015, with Application to Potential Radon Exposure from Groundwater and Indoor Air
}

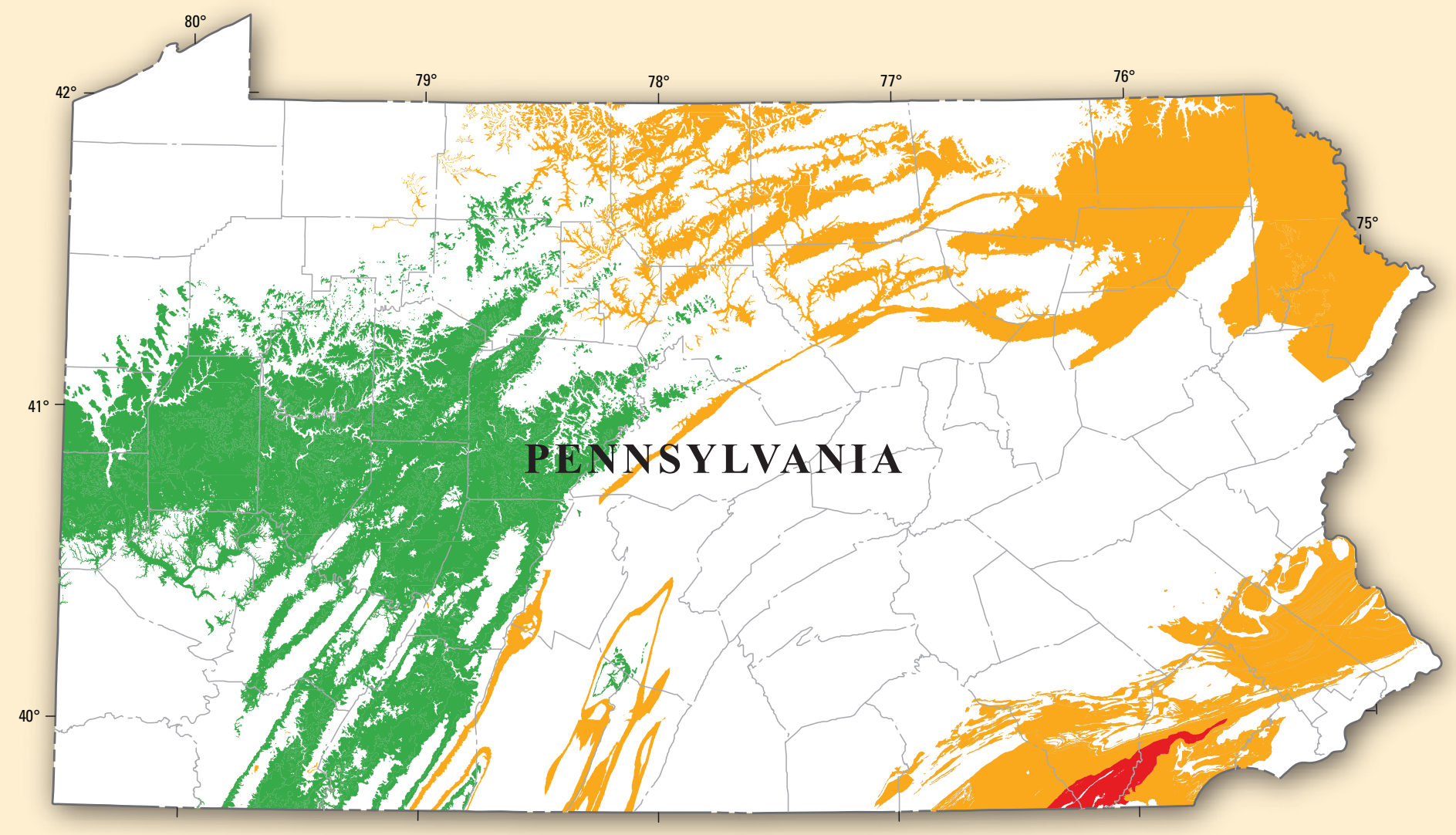

Scientific Investigations Report 2017-5018 
Cover. Map showing the 16 geologic-unit study area with geologic units shaded to indicate median radon concentrations in groundwater in Pennsylvania, 1986-2015. Green shading represents median radon concentration of less than 300 picocuries per liter (pCi/L); orange shading represents median radon concentration greater than or equal to $300 \mathrm{pCi} / \mathrm{L}$ and less than $4,000 \mathrm{pCi} / \mathrm{L}$; red shading represents median radon concentration greater than or equal to 4,000 pCi/L. Geologic unit digital data from Miles and Whitfield, 2001. 


\section{Evaluation of Radon Occurrence in Groundwater from 16 Geologic Units in Pennsylvania, 1986-2015, with Application to Potential Radon Exposure from Groundwater and Indoor Air}

By Eliza L. Gross

Prepared in cooperation with the

Pennsylvania Department of Health and the

Pennsylvania Department of Environmental Protection

Scientific Investigations Report 2017-5018 


\title{
U.S. Department of the Interior \\ RYAN K. ZINKE, Secretary
}

\section{U.S. Geological Survey William H. Werkheiser, Acting Director}

\author{
U.S. Geological Survey, Reston, Virginia: 2017
}

For more information on the USGS - the Federal source for science about the Earth, its natural and living resources, natural hazards, and the environment—visit http://www.usgs.gov or call 1-888-ASK-USGS.

For an overview of USGS information products, including maps, imagery, and publications, visit https://store.usgs.gov/.

Any use of trade, firm, or product names is for descriptive purposes only and does not imply endorsement by the U.S. Government.

Although this information product, for the most part, is in the public domain, it also may contain copyrighted materials as noted in the text. Permission to reproduce copyrighted items must be secured from the copyright owner.

Suggested citation:

Gross, E.L., 2017, Evaluation of radon occurrence in groundwater from 16 geologic units in Pennsylvania, 1986-2015, with application to potential radon exposure from groundwater and indoor air: U.S. Geological Survey Scientific Investigations Report 2017-5018, 24 p., https://doi.org/10.3133/sir20175018. 


\section{Acknowledgments}

This work was performed in collaboration with the Pennsylvania Environmental Public Health Tracking Program that was funded by the Centers for Disease Control and Prevention (CDC) by

Cooperative Agreement Number, 5U38EH000952-05. Its contents are solely the responsibility of the author and do not necessarily represent the official views of the CDC or the Department of Health and Human Services.

For further information regarding radon in Pennsylvania, visit the Pennsylvania Department of Environmental Protection (PADEP) Radon Division Website at http://dep.pa.gov/radon or call the PADEP Radon Hotline at 1-800-237-2366 or the PADEP Radon Division at 717-783-3594. 


\section{Contents}

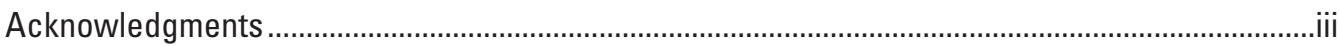

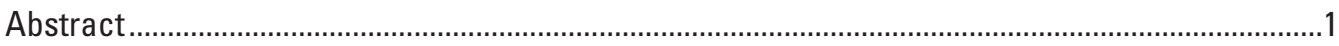

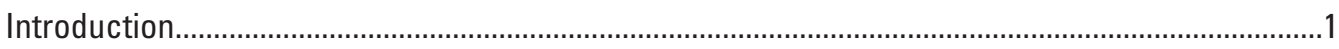

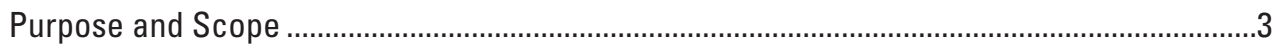

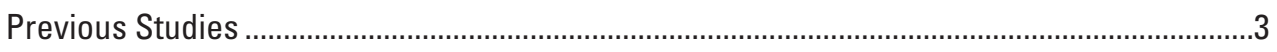

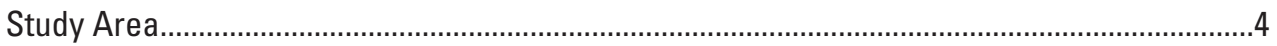

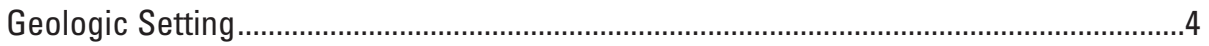

Sources of Radon .........................................................................................................

Population and Public Water Supply ...........................................................................

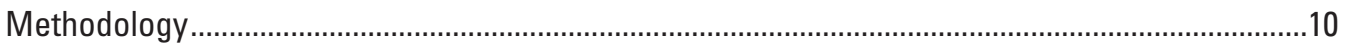

Evaluation of Radon Occurrence in Groundwater from 16 Geologic Units...................................12

Radon Concentrations in Groundwater by Geologic Unit.....................................................12

Potential Radon Exposure from Groundwater and Indoor Air ......................................................16

Variations in Radon Concentrations in Groundwater and Indoor Air by Geologic Unit..........16

Classification of Potential Radon Exposure from Groundwater and Indoor Air by Geologic

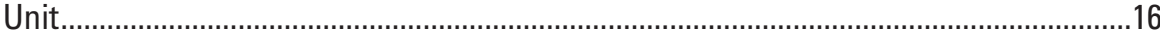

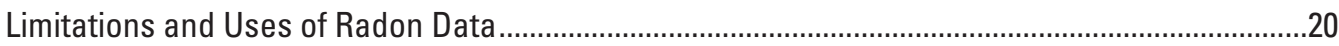

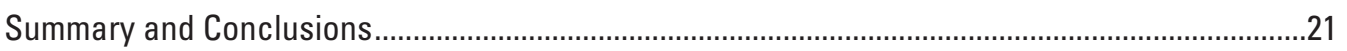

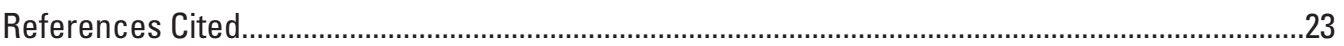

\section{Figures}

1. Map showing geologic units in the Appalachian Plateaus and Piedmont Physiographic Provinces of Pennsylvania that have 25 or more measurements of radon concentrations in groundwater from wells.

2. Map showing aerial gamma-ray survey of the gamma-ray influx produced by the radioactive decay of the naturally occurring element uranium within the 16 geologic-unit study area in Pennsylvania.

3. Map showing population density, major cities, and public water-supply service areas within the 16 geologic-unit study area in Pennsylvania, 2010

4. Map showing spatial distribution of radon concentrations in groundwater in Pennsylvania within the 16 geologic-unit study area, 1986-2015

5. Map showing geologic units with median radon concentrations of less than 300 to greater than 4,000 picocuries per liter in groundwater in Pennsylvania, 1986-2015 ......15

6. Boxplots showing distribution of radon concentrations in $A$, groundwater and $B$, indoor air for 16 geologic units in Pennsylvania, 1986-2015

7. Map showing geologic units and associated potential radon exposure from groundwater and indoor air in Pennsylvania, 1986-2015 


\section{Tables}

1. Characteristics of 16 geologic units associated with 25 or more measured concentrations of radon in groundwater samples collected from wells,

Pennsylvania, 1986-2015.

2. Potential radon exposure classifications for geologic units based on radon in groundwater and radon in indoor air classified according to proposed and recommended regulatory limits.

3. Summary statistics for radon concentrations in groundwater samples, by geologic unit, in Pennsylvania, 1986-2015, listed in order of increasing median concentrations.

4. Potential radon exposure from groundwater and indoor air, with median radon concentrations and the calculated percentage of the population within each geologic unit in Pennsylvania assumed to be using self-supplied water, 1986-2015 .....18 


\section{Conversion Factors}

U.S. customary units to International System of Units

\begin{tabular}{|c|c|c|}
\hline Multiply & By & To obtain \\
\hline \multicolumn{3}{|c|}{ Length } \\
\hline foot $(\mathrm{ft})$ & 0.3048 & meter $(\mathrm{m})$ \\
\hline \multicolumn{3}{|c|}{ Area } \\
\hline square mile $\left(\mathrm{mi}^{2}\right)$ & 2.590 & square kilometer $\left(\mathrm{km}^{2}\right)$ \\
\hline \multicolumn{3}{|c|}{ Radioactivity } \\
\hline picocurie per liter $(\mathrm{pCi} / \mathrm{L})$ & 0.037 & becquerel per liter $(\mathrm{Bq} / \mathrm{L})$ \\
\hline
\end{tabular}

\section{Datum}

Vertical coordinate information is referenced to the North American Vertical Datum of 1988 (NAVD 88). 


\title{
Evaluation of Radon Occurrence in Groundwater from 16 Geologic Units in Pennsylvania, 1986-2015, with Application to Potential Radon Exposure from Groundwater and Indoor Air
}

\author{
By Eliza L. Gross
}

\section{Abstract}

Results from 1,041 groundwater samples collected during 1986-2015 from 16 geologic units in Pennsylvania, associated with 25 or more groundwater samples with concentrations of radon-222, were evaluated in an effort to identify variations in radon-222 activities or concentrations and to classify potential radon-222 exposure from groundwater and indoor air. Radon222 is hereafter referred to as "radon." Radon concentrations in groundwater greater than or equal to the proposed U.S. Environmental Protection Agency (EPA) maximum contaminant level (MCL) for public-water supply systems of 300 picocuries per liter $(\mathrm{pCi} / \mathrm{L})$ were present in about 87 percent of the water samples, whereas concentrations greater than or equal to the proposed alternative MCL (AMCL) for public watersupply systems of $4,000 \mathrm{pCi} / \mathrm{L}$ were present in 14 percent. The highest radon concentrations were measured in groundwater from the schists, gneisses, and quartzites of the Piedmont Physiographic Province.

In this study, conducted by the U.S. Geological Survey in cooperation with the Pennsylvania Department of Health and the Pennsylvania Department of Environmental Protection, groundwater samples were aggregated among 16 geologic units in Pennsylvania to identify units with high median radon concentrations in groundwater. Graphical plots and statistical tests were used to determine variations in radon concentrations in groundwater and indoor air. Median radon concentrations in groundwater samples and median radon concentrations in indoor air samples within the 16 geologic units were classified according to proposed and recommended regulatory limits to explore potential radon exposure from groundwater and indoor air. All of the geologic units, except for the Allegheny (Pa) and Glenshaw (Pcg) Formations in the Appalachian Plateaus Physiographic Province, had median radon concentrations greater than the proposed EPA MCL of $300 \mathrm{pCi} / \mathrm{L}$, and the Peters Creek Schist (Xpc), which is in the Piedmont Physiographic Province, had a median radon concentration greater than the EPA proposed AMCL of 4,000 pCi/L. Median concentrations of radon in groundwater and indoor air were determined to differ significantly among the geologic units (Kruskal-Wallis test, significance probability, $\mathrm{p}<0.001$ ), and Tukey's test indicated that radon concentrations in groundwater and indoor air in the Peters Creek Schist (Xpc) were significantly higher than those in the other units. Also, the Peters Creek Schist (Xpc) was determined to be the area with highest potential of radon exposure from groundwater and indoor air and one of two units with the highest percentage of population assumed to be using domestic self-supplied water ( 81 percent), which puts the population at greater potential of exposure to radon from groundwater.

Potential radon exposure determined from classification of geologic units by median radon concentrations in groundwater and indoor air according to proposed and recommended regulatory limits is useful for drawing general conclusions about the presence, variation, and potential radon exposure in specific geologic units, but the associated data and maps have limitations. The aggregated indoor air radon data have spatial accuracy limitations owing to imprecision of geocoded test locations. In addition, the associated data describing geologic units and the public water supplier's service areas have spatial and interpretation accuracy limitations. As a result, data and maps associated with this report are not recommended for use in predicting individual concentrations at specific sites nor for use as a decision-making tool for property owners to decide whether to test for radon concentrations at specific locations. Instead, the data and maps are meant to promote awareness regarding potential radon exposure in Pennsylvania and to point out data gaps that exist throughout the State.

\section{Introduction}

Exposure to radon-222 activities or concentrations (hereafter referred to as radon and described in terms of concentrations) in indoor air has been identified as the second-leading cause of lung cancer (U.S. Environmental Protection Agency, 
1992). Radon, which is a colorless, odorless, and radioactive gas, is the most abundant and longest-lived radioisotope of the noble gas radon and is produced by the radioactive decay of radium-226, which is derived from the decay of uranium-238. Uranium-238 is present in small amounts in many minerals and may be present naturally in soil and bedrock. Once it moves from its source in rocks and soils, radon can enter buildings as a gas through the foundation and foundation cracks. In the saturated zone, it can dissolve in groundwater, be carried to water-supply wells, then be ingested through drinking water. Radon dissolved in drinking water is also released into indoor air when the water leaves the faucet to be used for showering, cleaning, or other purposes (Folger and others, 1994), which adds to the radon that enters the building through foundation cracks. However, radon primarily gets into the indoor air from soil gas (Gunderson and Smoot, 1993). Groundwater can be a notable indoor air radon source in those areas where groundwaters have extreme radon concentrations (Hess and others, 1987). The current standard recommended by the U.S. Environmental Protection Agency (EPA) for radon in indoor air to protect human health is 4 picocuries per liter (pCi/L; U.S. Environmental Protection Agency, 2011). The EPA recommends that homes receive additional long-term monitoring (test remains in home for more than 90 days) if initial short-term testing (test remains in home for 2 to 90 days) for radon in indoor air detects radon concentrations of $4 \mathrm{pCi} / \mathrm{L}$ or greater and that homes receive mitigation if radon concentrations of $4 \mathrm{pCi} / \mathrm{L}$ or greater are confirmed (U.S. Environmental Protection Agency, 2012). If measured indoor air concentrations are between 2 and $4 \mathrm{pCi} / \mathrm{L}$, the EPA recommends that homeowners still consider reducing radon levels in homes because any radon exposure is believed to carry some cancer risk (U.S. Environmental Protection Agency, 2012).

The main risk to human health from radon in water is associated with inhalation when radon degases from water into air (National Research Council, 1999). In Pennsylvania, large numbers of people rely on groundwater for drinking-water supply. People are primarily exposed to radon from groundwater in two ways: (1) inhalation of radon that has been released from the water during household activities when the water is heated or agitated, such as with showering, washing clothes, or washing dishes and (2) ingestion by drinking the water. Inhalation of radon has been recognized as a health risk and has been linked to lung cancer occurrence increases. Radon gas and its decay products may accumulate in the lungs when inhaled and damage lung tissue (World Health Organization, 2009). Most radon is typically exhaled before causing much damage, but decay products (polonium) can become attached to dust, smoke, or other fine particles from the air and remain trapped in the lungs, which increases cancer risk. Attempts have been made to link the ingestion of radon from drinking water to stomach cancer, but the risk has been found to be extremely small, representing a small fraction of the risk incurred from inhalation of radon degassing from water (National Research Council, 1999). The EPA does not currently regulate radon in drinking water. The ingestion of radon in water still poses a direct health risk through irradiation of sensitive cells in the gastrointestinal tract and other organs (National Research Council, 1999).

Although there is no established maximum contaminant level (MCL) for radon in drinking water, the EPA is developing a regulation to limit the amount of radon in public drinking-water supplies. Under the framework specified by the 1996 Amendments to the Safe Water Drinking Act (42 USC $\S 300$ f to $300 \mathrm{j}-26$ ), the EPA has proposed that states without enhanced indoor air programs require public water suppliers to reduce radon levels in drinking water to a MCL of 300 picocuries per liter $(\mathrm{pCi} / \mathrm{L})$, which was the proposed MCL for radon withdrawn in 1997. The EPA has also proposed to require public water suppliers to provide water with radon levels no higher than an alternative MCL (AMCL) of $4,000 \mathrm{pCi} / \mathrm{L}$ for states that have enhanced indoor air programs (U.S. Environmental Protection Agency, 2011). This requirement, which includes a higher AMCL than MCL, assumes that the state is taking action to reduce radon levels in indoor air by developing EPA-approved, enhanced state radon in indoor air programs (called Multimedia Mitigation Programs), which Pennsylvania currently uses.

Radon concentrations generally are greater in groundwater than in surface water; thus, the release of radon from water into air space potentially is a greater problem in buildings receiving drinking water from small community water systems accessing groundwater sources or domestic self-supply wells than in buildings receiving public water supply. Most large public water suppliers use surface water, and public water suppliers relying on groundwater typically process it in a manner that causes most dissolved radon to degas and release into the atmosphere before distribution to consumers. Because of reliance on surface water and processing of groundwater used for public consumption, radon concentrations are expected to be relatively low in many public water-supply systems. An evaluation of the occurrence of radon concentrations in indoor air in Pennsylvania has recently been completed (Gross, 2013). In spite of regional studies, an evaluation of radon in groundwater in Pennsylvania has not been completed using all existing data for radon concentrations for the State. Management of a program such as the Multimedia Mitigation Program for radon in the State may be enhanced by the knowledge of where the sources of radon in indoor air and groundwater are most elevated or least elevated because different outreach strategies may be needed in different areas.

The limits proposed by the EPA do not apply to drinking water obtained from domestic self-supply wells, and the relative contribution of radon from groundwater to indoor air is not known, although each $10,000 \mathrm{pCi} / \mathrm{L}$ in water has been estimated to increase indoor air concentrations by $1 \mathrm{pCi} / \mathrm{L}$ and thus increase health risks (Milry and Cothern, 1990; Prichard, 1987). The 10,000:1 water:air radon ratio varies considerably from house to house and is a general national average (National Research Council, 1999). Total radon exposure for the residential homeowner is the sum of exposure to radon in indoor air, short-term peak radon doses derived from water 
sources and inhaled before dissipation (shower, dishwasher, laundry dose), and the very small dose from ingestion of water (National Research Council, 1999). The overall inhalation dose from the water source is accounted for by the amount that the level of radon in the indoor air is increased by the radon degassing from the water. Most of this dose is obtained through the overall increase in the indoor radon concentration in the house, especially if the concentrations in the groundwater are high. However, a notable instantaneous inhalation dose from radon released to air in confined indoor space (most specifically while showering) may be added to the long-term inhalation dose (Bernhardt and Hess, 1996; Vinson and others, 2008). Considerable amounts of the radon decay product, metallic polonium-218, builds up within minutes of the release of radon and can become lodged in lung tissue. This instantaneous or short-term dose is in addition to the increase in general or long-term dose that originates from the overall increase in radon concentration level in indoor air from the other household uses of the water for which there is no direct contact.

Strategies for removal of radon from air that enters buildings from soil gas differ from those used to remediate radon that enters buildings through the use of groundwater. Therefore, the sources of radon contamination and the mechanism of entry of radon into the home provide valuable information to homeowners. For example, typical radon remediation that occurs in a basement will not remediate radon entering the home from groundwater supplies used to shower, wash dishes, or wash laundry. The concern is the addition of substantial inhalation dose obtained immediately by the homeowner present in the room in which the radon is degassed (Bernhardt and Hess, 1996; Vinson and others, 2008), but the increase in overall indoor air radon concentration in the living space from the water use is also a concern.

Evaluation of the occurrence of radon in groundwater according to geologic units and regulatory limits has not been attempted on a large spatial scale in Pennsylvania. Data on radon concentrations in groundwater in Pennsylvania are limited. However, where data are available, information about the occurrence of radon concentrations in groundwater that are elevated above background conditions may be useful in identifying contributions to health risks and in assessing likely remediation options. Recognizing the need for a better understanding of potential radon exposure, the U.S. Geological Survey (USGS), in cooperation with the Pennsylvania Department of Environmental Protection and Pennsylvania Department of Health, evaluated data on radon concentrations in groundwater in 16 geologic units throughout the State for which ample data are available.

\section{Purpose and Scope}

The purpose of this report is to (1) present an evaluation of radon concentrations in groundwater for data-rich geologic units of Pennsylvania, which for the purposes of this report are defined as those units with 25 or more observations of radon concentrations available from the USGS National Water Information System (U.S. Geological Survey, 2016); (2) identify the variation between concentrations of radon in groundwater and indoor air according to geologic unit; (3) determine geologic units with potential radon exposure across Pennsylvania through comparison of aggregated concentrations of radon in groundwater and indoor air classified according to regulatory limits and in relation to public water-supply service areas; and (4) document methods, statistical results, and study limitations in a statewide spatial dataset and metadata (Gross, 2017).

\section{Previous Studies}

Radon concentrations in groundwater have been measured across Pennsylvania by the USGS and are described in various reports, such as those by Lindsey and Ator (1996), Senior (1998), Sloto (2000), Senior (2009), Johnson and others (2011), Chapman and others (2013), Sloto (2013), Senior (2014), Sloto (2014), Senior and others (2016), and Gross and Cravotta (2017), for selected counties and regions. Lindsey and Ator (1996) examined radon concentrations in groundwater samples collected from 267 bedrock wells in the Lower Susquehanna and Potomac River Basins, which include a portion of south-central Pennsylvania. They found that 80 percent of the groundwater samples collected for their study contained radon concentrations greater than the proposed EPA MCL of $300 \mathrm{pCi} / \mathrm{L}$ and that areas underlain by the igneous and metamorphic rocks of the Piedmont Physiographic Province, which is partially located in southeastern Pennsylvania, had the highest median $(3,100 \mathrm{pCi} / \mathrm{L})$ and overall $(38,000 \mathrm{pCi} / \mathrm{L})$ groundwater radon concentrations. Regional assessment of radon in groundwater in the Piedmont and Blue Ridge Crystalline-Rock aquifers and Piedmont Early Mesozoic-Rock aquifers of the eastern United States included data on radon in water from these aquifers in the Piedmont Physiographic Province of southeastern Pennsylvania; 90 percent of the samples had radon concentrations greater than $300 \mathrm{pCi} / \mathrm{L}$ (Chapman and others, 2013). Other studies in the Piedmont Physiographic Province in Pennsylvania have reported similar results. For example, 89 percent of 665 groundwater samples from Chester County had radon concentrations that exceeded $300 \mathrm{pCi} / \mathrm{L}$ (Senior, 1998). Results reported by Sloto (2000) for groundwater samples collected in the Piedmont Physiographic Province in southeastern Pennsylvania indicate that 89 percent of water samples collected from 912 wells had radon concentrations that exceeded $300 \mathrm{pCi} / \mathrm{L}$ and 16 percent of samples had concentrations that exceeded the proposed EPA AMCL of $4,000 \mathrm{pCi} / \mathrm{L}$.

Another regional assessment conducted from 1993 to 2002 included the collection of groundwater samples from 230 wells completed within the aquifers in the Ridge and Valley Physiographic Province, which extends from south-central to northeastern Pennsylvania (Johnson and others, 2011).

Radon concentrations exceeded $300 \mathrm{pCi} / \mathrm{L}$ at 74 percent and $4,000 \mathrm{pCi} / \mathrm{L}$ at 2 percent of the wells sampled, and all samples that had radon concentrations exceeding $4,000 \mathrm{pCi} / \mathrm{L}$ were 
Evaluation of Radon Occurrence in Groundwater from 16 Geologic Units in Pennsylvania, 1986-2015

collected from wells in siliciclastic-rock aquifers (Johnson and others, 2011). These findings are similar to those reported in two studies describing results for a reconnaissance groundwater-quality assessment in Pike County (Senior, 2009; Senior, 2014), which is in northeastern Pennsylvania and is located in the Appalachian Plateaus Physiographic Province. Of 20 wells that were sampled in 2007,75 percent had radon levels greater than or equal to $300 \mathrm{pCi} / \mathrm{L}$, and none exceeded $4,000 \mathrm{pCi} / \mathrm{L}$ (Senior, 2009). Of the 20 wells sampled in Pike County in 2012, 85 percent had radon levels exceeding $300 \mathrm{pCi} / \mathrm{L}$, and two samples had radon concentrations exceeding 4,000 pCi/L (Senior 2014). The distribution of radon concentrations in the 2012 samples were similar to results from the 2007 samples, in which radon concentrations in groundwater appeared to differ by geologic unit and were highest in water samples from wells completed in the Catskill Formation, considered a silciclastic geologic unit owing to its primarily sandstone lithology (Senior, 2014).

Groundwater samples were collected from 32 wells in 2011 and 2 wells in 2013 in Wayne County, which is adjacent to western Pike County and primarily is underlain by the Catskill Formation and its members in the Appalachian Plateaus Physiographic Province (Sloto, 2014). Radon concentrations in 97 percent of the samples exceeded $300 \mathrm{pCi} / \mathrm{L}$, whereas 12 percent of samples had concentrations exceeding 4,000 pCi/L (Sloto, 2014). A study sampling 89 wells in 2014 expanded on the 2011 and 2013 sampling efforts; radon concentrations in the 2014 study exceeded $300 \mathrm{pCi} / \mathrm{L}$ in 97 percent of the samples and 4,000 $\mathrm{pCi} / \mathrm{L}$ in 14 percent of the samples (Senior and others, 2016). Groundwater samples were collected in 2012 from 20 wells in Sullivan County, which is two counties west of Wayne County; 85 percent of those samples had radon concentrations exceeding $300 \mathrm{pCi} / \mathrm{L}$, and 10 percent had radon concentrations exceeding $4,000 \mathrm{pCi} / \mathrm{L}$. Four samples with concentrations exceeding $300 \mathrm{pCi} / \mathrm{L}$ were collected from wells in the Catskill Formation in the Appalachian Plateaus Physiographic Province (Sloto, 2013). Similar results were reported for groundwater samples collected in 2014 from 75 wells in Lycoming County, which shares Sullivan County's western boundary; radon concentrations exceeded $300 \mathrm{pCi} / \mathrm{L}$ in 67 percent of samples and $4,000 \mathrm{pCi} / \mathrm{L}$ in 4 percent of samples. Three samples with radon concentrations greater than $4,000 \mathrm{pCi} / \mathrm{L}$ were from geologic units primarily consisting of sandstone (Gross and Cravotta, 2017).

As part of a 2013 (Gross) study, results from 548,507 indoor radon tests collected in Pennsylvania from 1990 to 2007 and compiled in a database by the Pennsylvania Department of Environmental Protection (PADEP), Bureau of Radiation Protection, Radon Division were aggregated according to 188 geologic units and 20 hydrogeologic settings to determine areas in the State where concentrations of radon in indoor air are highest. The indoor air radon concentration data are from indoor tests conducted in Pennsylvania and submitted to the PADEP by certified laboratories and testers. Most of the testing occurred during real estate transactions. For the purposes of analyses presented in Gross (2013), the original dataset of
878,160 test results was edited to include only records with geocoding precision scores equal to 100 (scores can range from 0 to 100 and are a measure of confidence of geocoding precision), basement testing locations, short-term test results (results from tests lasting less than or equal to 90 days), and test results that were greater than or equal to zero (to remove test results that did not have a reported value). Numerical values of test results were otherwise reported as obtained from the PADEP indoor air radon concentration database. Because the Pennsylvania bedrock geology dataset (Miles and Whitfield, 2001) was used for aggregating most analyses, a geographic information system (GIS) was used to remove two records with spatial coordinates that did not fall within the boundaries designated by the geology dataset. Nevertheless, even geocoding precision scores equal to 100 can be inaccurate by as much as 700 feet, which poses minor classification limitations in a small number of cases (Gross, 2013). After all edits were completed, the final dataset contained 548,507 test results, which were aggregated according to geologic units and hydrogeologic settings. Of the geologic units, 93 of the 188 (49.5 percent) geologic units with indoor air radon concentrations had median concentrations greater than the EPA action level of $4 \mathrm{pCi} / \mathrm{L}$, whereas 5 of the 20 ( 25 percent) hydrogeologic settings had median indoor air radon concentrations greater than $4 \mathrm{pCi} / \mathrm{L}$. Geologic units with median indoor air radon concentrations exceeding $4 \mathrm{pCi} / \mathrm{L}$ were in the eastern part of the State and included metamorphic rocks, limestones, sandstones, shales, and glacial deposits, and those hydrogeologic settings with indoor air radon concentrations exceeding $4 \mathrm{pCi} / \mathrm{L}$ were in carbonate settings within the Ridge and Valley Physiographic Province in the south-central part of the State.

\section{Study Area}

For the purposes of this study, the study area is limited to the areas overlain by 16 geologic units in Pennsylvania with 25 or more measurements of radon concentrations in groundwater (table 1; fig. 1). The extent of these 16 geologic units encompasses approximately 14,196 square miles $\left(\mathrm{mi}^{2}\right)$ of the 45,306- $\mathrm{mi}^{2}$ State. The smallest unit is the Felsic and intermediate gneiss (ggd; $63 \mathrm{mi}^{2}$ ) in the Piedmont Physiographic Province, and the largest unit is the Catskill Formation $\left(\mathrm{Pa} ; 4,515 \mathrm{mi}^{2}\right)$ in the Appalachian Plateaus Physiographic Province.

\section{Geologic Setting}

Geologic units within the study area can be categorized according to 5 units primarily in the Appalachian Plateaus Physiographic Province of northern and western Pennsylvania and 11 units in the Piedmont Physiographic Province of southeastern Pennsylvania (table 1; fig. 1). Geologic units in the Appalachian Plateaus Physiographic Province consist mostly of sandstone and shale rock types with some conglomerate; areas in the northern part of the physiographic province may 


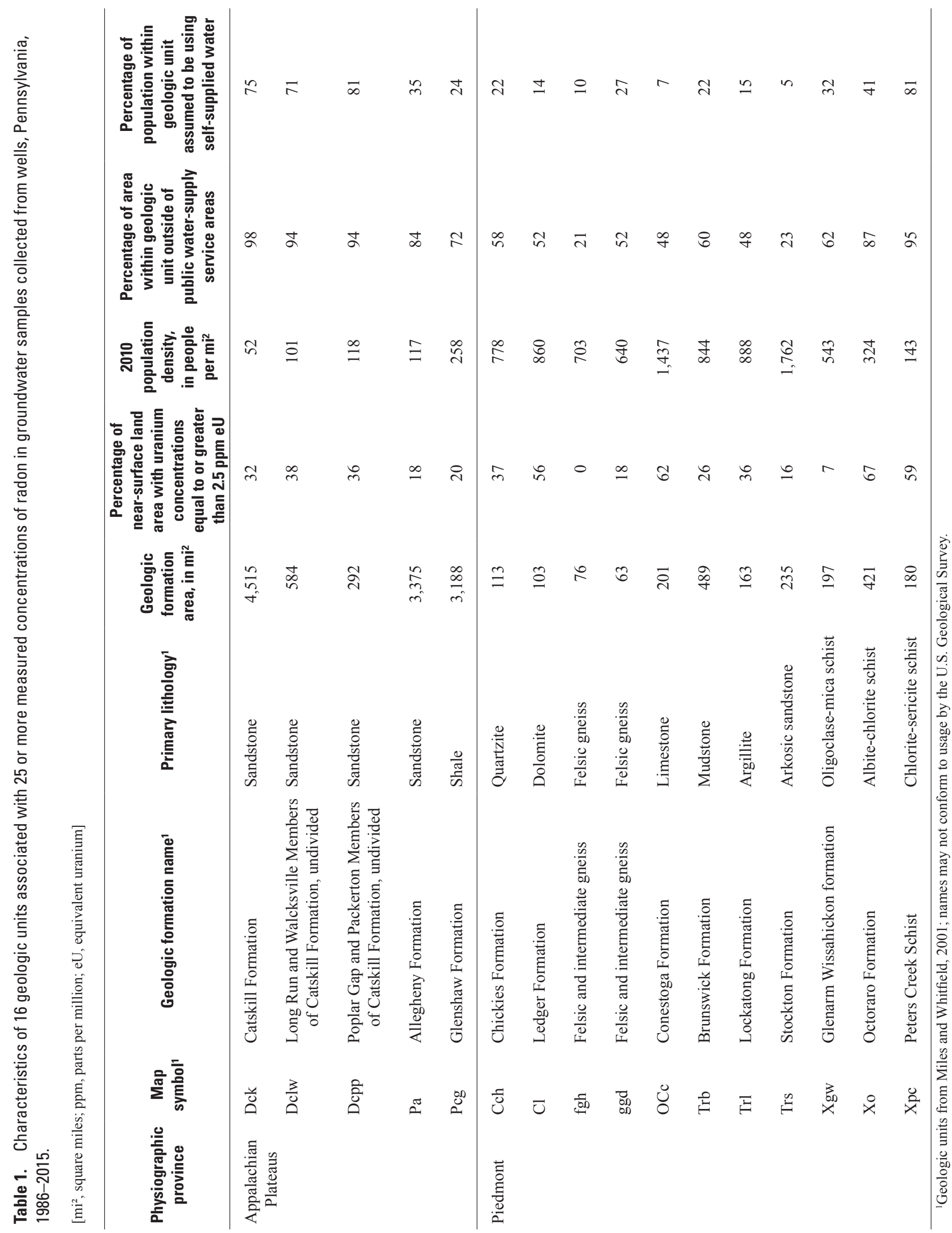




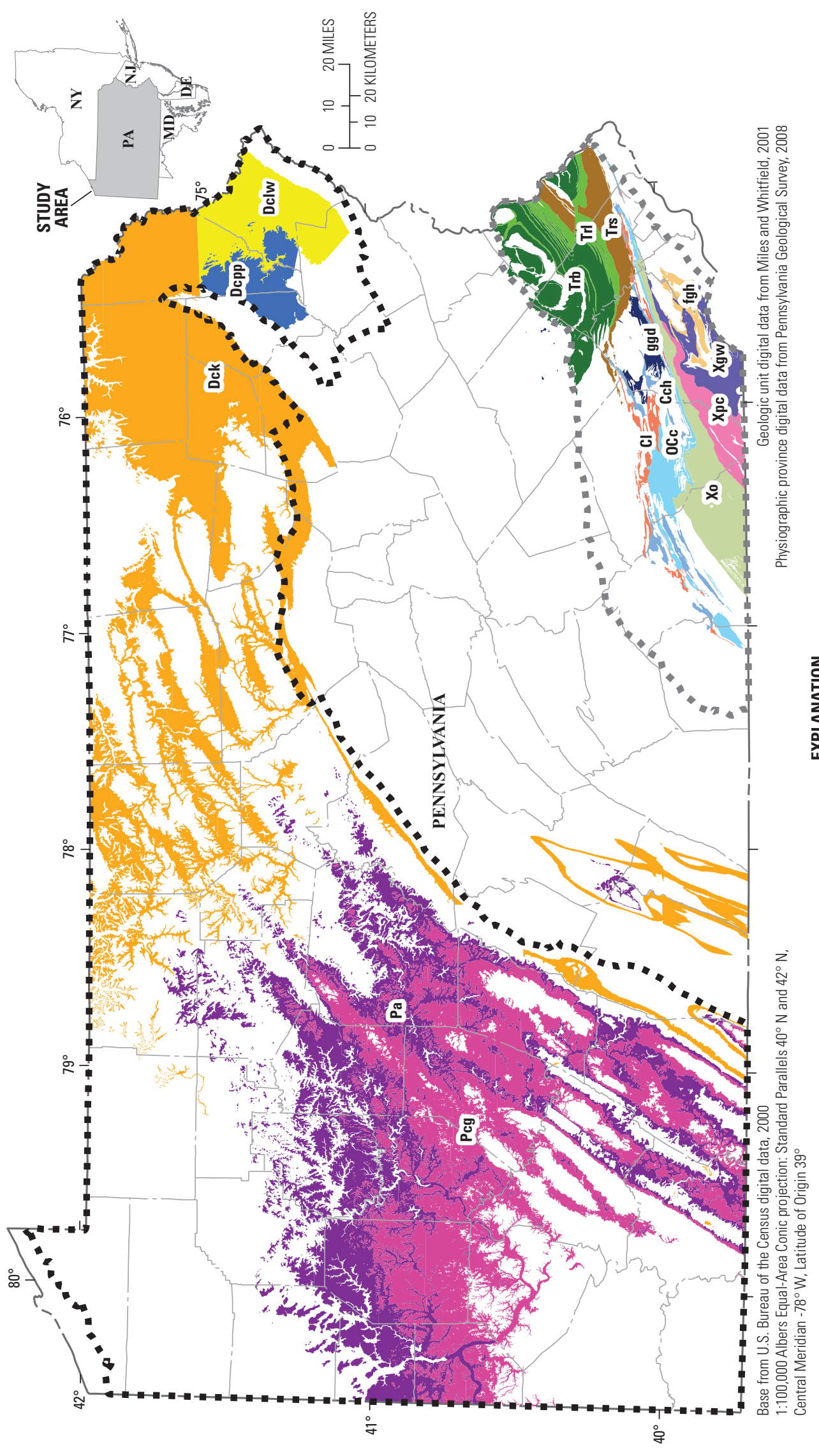

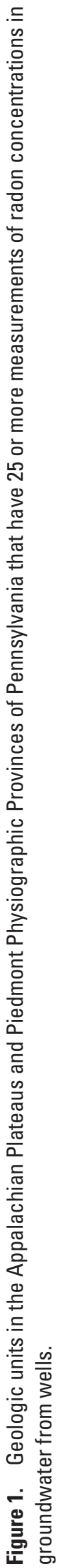


contain alluvium and glacial outwash overlying the bedrock (Sevon, 1975; Miles and Whitfield, 2001). On the other hand, the units in the Piedmont Physiographic Province consist of highly variable igneous, metamorphic, and sedimentary rocks along with diabase sills and dikes (Low and others, 2002).

\section{Sources of Radon}

Radon is a naturally occurring radionuclide produced from the radioactive decay of radium-226, a product of the uranium-238 decay series. The radon concentration in soil gas and groundwater generally increases with increase in the uranium-238 (hereafter referred to as "uranium") content of the soil and bedrock (Wanty and others, 1992). Uranium is ubiquitous in rocks and soils; typically, the largest concentrations are in shales, metamorphic rocks derived from shales, and granites. Common sources of radon in rocks include uranium-bearing minerals and amorphous oxides formed by weathering that contain radionuclide-progeny-bearing phases produced by the decay of uranium. The radioactive decay of uranium and radionuclide progeny result in the emission of gamma rays, which can be measured using instruments in aircraft flying low to the ground as long as emissions are of sufficient intensity (Duval and others, 2005). These aerial gamma-ray surveys measure the gamma-ray flux produced by the radioactive decay of the naturally occurring uranium in the top few centimeters of rock or soil, and the data can be processed to produce maps showing surface concentrations of uranium (fig. 2). Although these maps are more indicative of the radioactivity of soils than bedrock, the data are useful for gaining an overall view of near-surface radioactivity and the potential for anomalously elevated concentrations of uranium, the primary source of radon.

In a 1995 study, Wedepohl (1995) estimated that the global upper continental crustal average for uranium was 2.5 parts per million. Aerial gamma-ray data indicate 4 of the 16 geologic units in the study area have more than 50 percent of near-surface land area with greater than the global upper continental crustal average equivalent uranium (eU) (fig. 2; table 1). These near-surface land areas are underlain by the Ledger Formation (Cl), Conestoga Formation (OCc), Octoraro Formation (Xo), and Peters Creek Schist (Xpc), which are in the Piedmont Physiographic Province (fig. 1). Since the Ledger Formation $(\mathrm{Cl})$ and Conestoga Formation $(\mathrm{OCc})$ are primarily composed of dolomite and limestone, respectively, elevated uranium concentrations may result from the soils overlying these formations that contain more uranium than the bedrock itself. The dissolution of carbonate rocks, such as dolomite and limestone, creates soils that are enriched in impurities, such as uranium (Gunderson and Smoot, 1993). On the other hand, the schists and gneisses that form the Octoraro Formation (Xo) and Peters Creek Schist (Xpc) are old uranium-rich metamorphic rocks that commonly form resistant ridges in outcrops (Turner-Peterson, 1988). Occasional uranium mineralization has been documented in the Catskill Formation (Dck) (Pirc and Rose, 1981).

\section{Population and Public Water Supply}

There are six cities within the study area with populations greater than 30,000 in 2010 (U.S. Bureau of the Census, 2010a). Three of these cities overlie geologic units in the Piedmont Physiographic Province of southeastern Pennsylvania, and the other three cities overlie the Appalachian Plateaus Physiographic Province of northern and western Pennsylvania (fig. 3). Cities with populations greater than 30,000 are Pittsburgh with a population of 305,704; Scranton, 76,089; Lancaster, 59,322; York, 43,718; Wilkes-Barre, 41,498; and Norristown, 34,324 (U.S. Bureau of the Census, 2010a) (fig. 3). The locations of these cities correspond to those areas of the State with the highest population densities (greater than or equal to 5,001 people per square mile) (fig. 3). The geologic unit with the smallest population density is the Catskill Formation (Dck; 52 people per square mile) in the Appalachian Plateaus Physiographic Province of northern and western Pennsylvania. The geologic unit with the largest population density is the Stockton Formation (Trs; 1,762 people per square mile) in the Piedmont Physiographic Province (table 1; fig. 1).

Areas with high population density typically overlap with public water-supply service areas (fig. 3 ), where the population is served by a public water supplier (Pennsylvania Department of Environmental Protection, 2013). Geospatial data describing public water-supply service areas were used to determine where privately supplied groundwater is assumed to be the primary water-supply source. For purposes of this study, areas outside of the public water-supply service areas, shown in figure 3 , were assumed to contain populations that self-supply their own water through the use of domestic self-supply wells. Those areas where privately supplied groundwater is the primary water supply are expected to have the greatest potential of radon exposure from groundwater because once the water is withdrawn from the ground, typically, it is used almost immediately; thus, the radon has little chance to diminish in concentration through radioactive decay, which might be the case for a large public supply system.

Approximately 83 percent of the study area is outside of public water-supply service areas and contains 27 percent of the total study area population, who are assumed to use domestic self-supply wells. The geologic unit underlying the lowest percentage of land area assumed to be using a self-supplied water supply ( 21 percent) is that underlain by the Felsic and intermediate gneiss (fgh) just west of Norristown in the Piedmont Physiographic Province. The geologic unit underlying the highest percentage of land area assumed to be using a self-supplied water supply ( 98 percent) is that underlain by the Catskill Formation (Dck) near Scranton and Wilkes-Barre in the Appalachian Plateaus Physiographic Province (table 1; figs. 1 and 3). The lowest percentage of the population assumed to be using a self-supplied water supply (5 percent) is in a densely populated area underlain by the Stockton Formation (Trs) north of Norristown in the Piedmont Physiographic Province, whereas the highest percentage of the population assumed to be using self-supplied water (81 percent) is south 


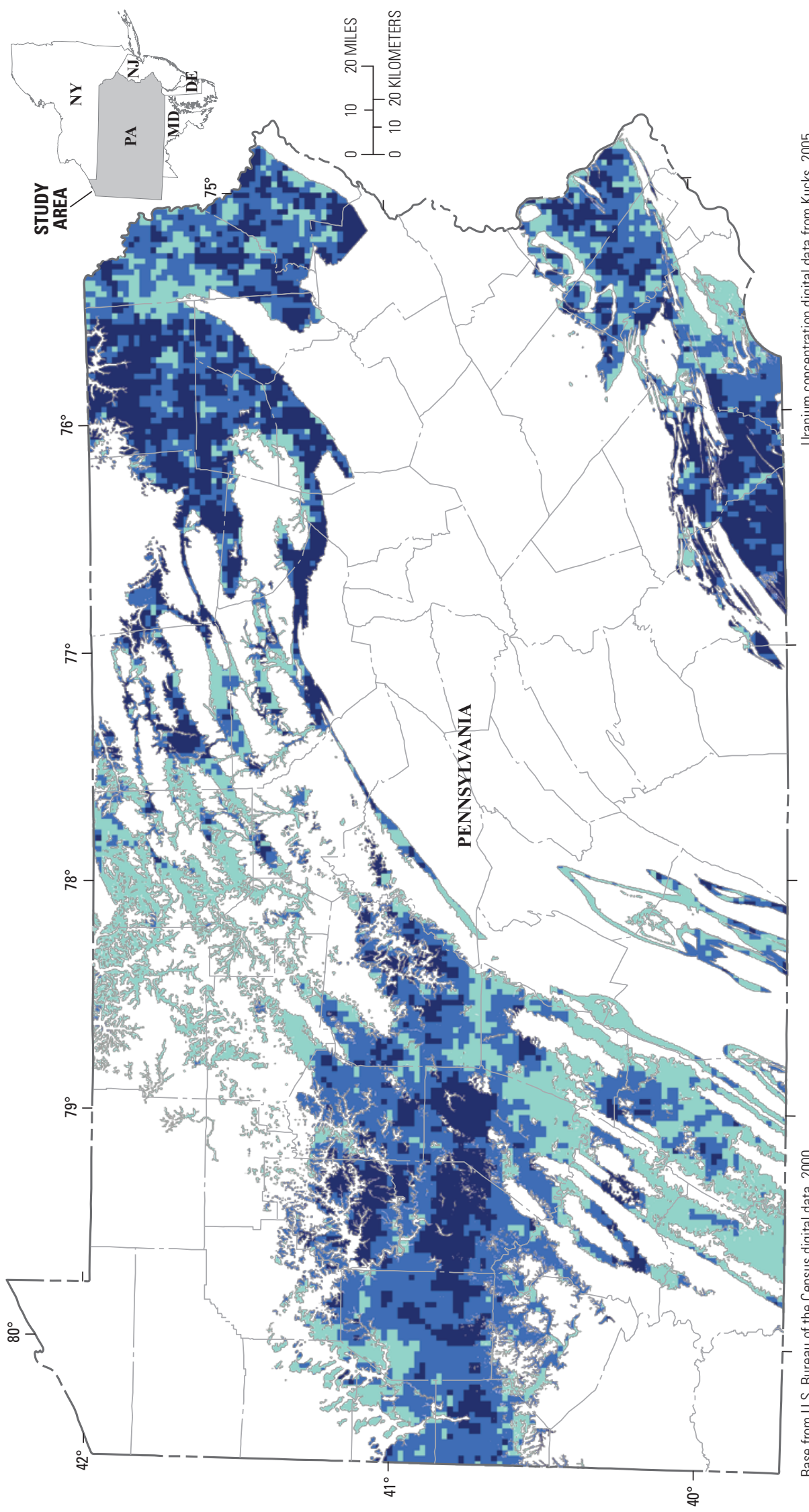

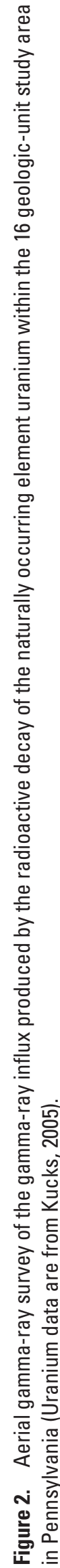



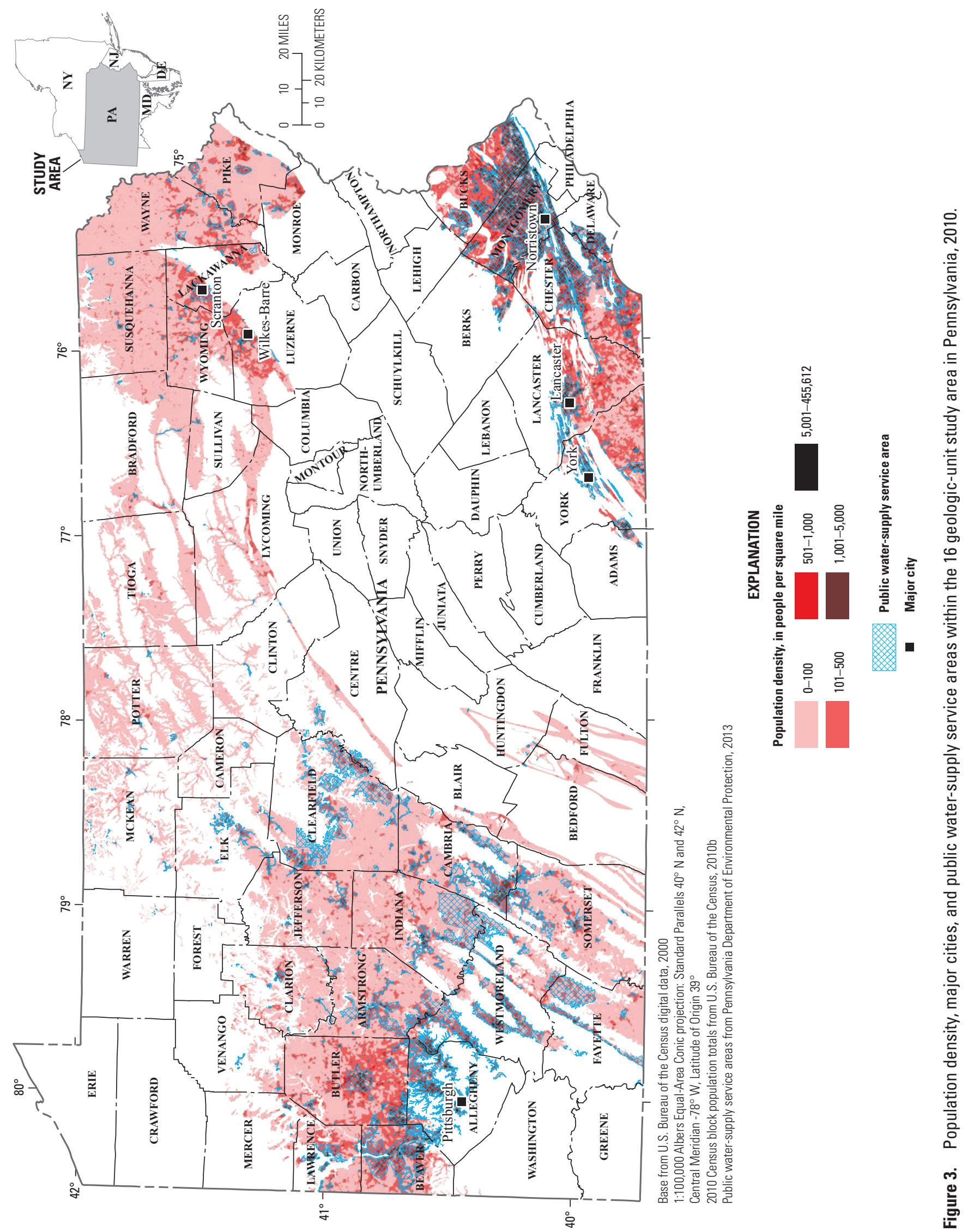
of Lancaster in areas underlain by the Peters Creek Schist (Xpc) in the Piedmont Physiographic Province and east of Scranton and Wilkes-Barre in areas underlain by the Poplar Gap and Packerton Members of the Catskill Formation, undivided (Dcpp) in the Appalachian Plateaus Physiographic Province (table 1; figs. 1 and 3).

\section{Methodology}

This study evaluated available data on radon in groundwater in the 16 data-rich geologic units in Pennsylvania (fig. 1). Data compiled for the study include (1) radon concentrations in groundwater (1986-2015) from wells measured by the USGS (U.S. Geological Survey, 2016), (2) a geospatial dataset of geologic units in Pennsylvania (Miles and Whitfield, 2001), (3) concentrations of radon in indoor air (from 1990-2007) aggregated by geologic unit (Gross, 2013), and (4) a geospatial dataset of public water-supply service areas (Pennsylvania Department of Environmental Protection, 2013). Geologic units used in the report are from the Pennsylvania Geological Survey dataset for the bedrock geology of Pennsylvania (Miles and Whitfield, 2001); names may not conform to usage by the U.S. Geological Survey.

Radon concentrations in groundwater samples collected by the USGS between 1986 and 2015 were compiled from the USGS National Water Information System (U.S. Geological Survey, 2016) database to identify areas with enough radon data for evaluation because these data are limited in areal extent throughout the State. Data describing concentrations of radon in 1,964 groundwater samples collected by the USGS from 1,671 wells were compiled for all aquifer and use types. A total of 130 of these wells were sampled more than once (ranging from 2 to 39 times); most of these wells are in Chester and Pike Counties because studies have been conducted in these counties (Senior and Vogel, 1995; Senior, 1998; Senior, 2009; Senior 2014; Sloto, 2000). For wells sampled more than once, the radon concentration from the first sampling event was used in statistical analysis for this study, resulting in the removal of 293 samples (Senior, 1998). For the purposes of this study, all wells were considered to be completed in the geologic unit that the well point intersects, determined on the basis of the bedrock geology map of Pennsylvania (Miles and Whitfield, 2001). No attempt was made to separate or remove wells completed in glacial aquifers because not all wells had aquifer information associated with the available well-construction information.

Radon concentrations in 1,671 groundwater samples were aggregated by geologic unit (Miles and Whitfield, 2001). Of the 188 recognized geologic units in Pennsylvania, a total of 120 geologic units (64 percent) contained radon in groundwater samples with amounts ranging from 1 to 75 , whereas the remaining 68 geologic units ( 36 percent) did not contain any radon in groundwater samples. Of these 120 geologic units, 16 geologic units (13 percent) contained 25 or more radon concentrations (Miles and Whitfield, 2001), resulting in a total of 1,041 samples used for data evaluation. A minimum of 25 groundwater samples per geologic unit was requisite because 25 is the minimum number of samples required to reliably define the sample population standard deviation (Noether, 1971) and test population normality (Razali and Wah, 2011); thus, geologic units containing 25 or more radon concentrations were defined as having a sufficient amount of data for evaluation. A total of 172 geologic units having 0-24 samples were determined to have insufficient data. Data on radon in groundwater for 630 wells within 104 geologic units having 1-24 samples were not included in evaluations presented in this report. Radon concentration data for the 1,041 remaining groundwater samples, representing the 16 geologic units having 25 or more samples of radon, were characterized by geologic unit using summary statistics (quartiles, skewness).

Aggregated data on radon concentrations in groundwater from the 16 geologic units with 25 or more samples were compared to aggregated radon concentrations in indoor air (Gross, 2013). Aggregated indoor air radon concentrations for the 16 geologic unit study area consisted of 195,783 of the 548,507 (36 percent) test results from the dataset compiled by Gross (2013) and were used to compile the aggregated indoor air radon data referred to in this report.

The median radon concentrations of groundwater and indoor air were tested for normality and compared across all 16 geologic units to determine potential differences in median concentrations of radon in groundwater and indoor air between geologic units. The Wilk-Shapiro test was used to determine the normality of the distribution of radon concentrations in groundwater and indoor air; the data were not normally distributed (Helsel and Hirsh, 1992). As a result, nonparametric statistics were used for further statistical analysis. Nonparametric statistics commonly are used to analyze data when the distribution of the data is unknown or not normal, such as environmental data that can be badly skewed. Nonparametric statistical analyses use ranked values of variables rather than actual values, thus nonparametric statistics can handle less-than values that arise when data are bounded at the detection limit of the analytical method and concentrations are reported as less than the minimum reporting level (MRL). None of the indoor air test results for radon were reported as less than a MRL, whereas 11 of the 1,041 (1 percent) groundwater samples had radon concentrations reported as "less than the MRL." MRLs for the 11 groundwater samples ranged from $64-80 \mathrm{pCi} / \mathrm{L}$. Also, one groundwater sample had a radon concentration of -11.6 and was reported as "radiochemical non-detect, below sample specific critical level." Because the groundwater samples had radon concentrations below multiple MRLs, the data were examined in order to determine the highest MRL, which was $80 \mathrm{pCi} / \mathrm{L}$. The 13 reported radon concentrations, ranging from 30 to $79 \mathrm{pCi} / \mathrm{L}$, that were below the highest MRL and the radiochemical non-detect were censored to the highest MRL of $80 \mathrm{pCi} / \mathrm{L}$. This enabled the use of all the data in nonparametric statistical analyses without making assumptions about the distribution of the data below the MRL 
(Helsel and Hirsch, 1992). For this study, less than 3 percent of the radon data were censored to the highest MRL of 80 $\mathrm{pCi} / \mathrm{L}$. Nonparametric statistics, which do not require distributional assumptions about data less than MRLs, were used to compare radon concentrations of groundwater and indoor air among geologic units. Statistical analyses, including summary statistics of radon concentration data for 1,041 groundwater samples, were performed using all data values, including censored data (data reported as below the MRL).

The non-parametric Kruskal-Wallis test was applied to the ranks of concentrations of radon in groundwater, and a separate test was applied to ranks of concentrations of radon in indoor air to test whether differences in median concentrations among the geologic units were statistically significant at an alpha level of 0.05 . If the calculated probability (p-value) is less than a specified alpha value of 0.05 , there is a 95 -percent probability that categories are significantly different, which means there is only a 1 in 20 chance that the observation is due to random variability in water or indoor air quality. A p-value of less than 0.05 indicates the median rank concentration from observations in at least one geologic unit was statistically different from the others (Helsel and Hirsh, 1992).

If differences in radon concentrations in groundwater and indoor air among the geologic units were statistically significant using the Kruskal-Wallis test, the Tukey test on ranked data was used to determine which geologic units had significantly different radon concentrations in groundwater and indoor air at an alpha level of 0.05 . The geologic units were simultaneously classified into Tukey's groups; the groups were represented sequentially by rank using the letters, or a combination of the letters, A through H. Geologic units in group A have the highest mean rank of radon concentrations in groundwater and indoor air, and those in groups B through $\mathrm{H}$ have successively lower median rank concentrations. Groups of geologic units that have radon concentration data that do not differ significantly from one another are assigned at least one letter in common, indicating membership in a common Tukey's group.

Geologic units having the most elevated concentrations of radon in groundwater were then compared spatially to areas with the most elevated concentrations of radon in indoor air (Gross, 2013) and areas served by public water-supply systems (Pennsylvania Department of Environmental Protection, 2013) to further refine the current understanding of potential radon exposure from indoor air and groundwater. Those areas where self-supplied groundwater is the primary water-supply source were expected to have the greatest potential of radon exposure from groundwater; hence, geospatial data describing the extent of the public water-supply systems used to determine the assumed primary water-supply source, self-supplied or public, were an important component of the data evaluation.

Geologic units containing sufficient data describing radon concentrations in groundwater were classified based on proposed groundwater regulatory limits: (1) radon concentrations in groundwater less than 300 picocuries per liter $(\mathrm{pCi} / \mathrm{L})$, (2) radon concentrations in groundwater greater than or equal to $300 \mathrm{pCi} / \mathrm{L}$ and less than $4,000 \mathrm{pCi} / \mathrm{L}$, and (3) radon concentrations in groundwater greater than or equal to $4,000 \mathrm{pCi} / \mathrm{L}$. Geologic units classified according to radon concentrations in groundwater were compared with geologic units classified according to radon concentrations in indoor air based on recommended indoor air regulatory limits: (1) radon concentrations in indoor air less than $2.0 \mathrm{pCi} / \mathrm{L},(2)$ radon concentrations in indoor air greater than or equal to $2.0 \mathrm{pCi} / \mathrm{L}$ and less than $4.0 \mathrm{pCi} / \mathrm{L}$, and (3) radon concentrations in indoor air greater than or equal to $4.0 \mathrm{pCi} / \mathrm{L}$. Aggregated radon concentrations in groundwater and indoor air were used to classify geologic units based on previously described radon in groundwater and radon in indoor air classifications to create nine potential radon exposure classifications, of which four were applicable to this study (table 2). Geologic units were mapped according to potential radon exposure classifications and maps

Table 2. Potential radon exposure classifications for geologic units based on radon in groundwater and radon in indoor air classified according to proposed and recommended regulatory limits.

[Shading indicates potential radon exposure risk from groundwater and indoor air from lowest (yellow) to highest (red) with classifications shaded gray not applicable to this study; $\mathrm{pCi} / \mathrm{L}$, picocuries per liter]

\begin{tabular}{|c|c|c|c|c|}
\hline \multirow{2}{*}{\multicolumn{2}{|c|}{$\begin{array}{l}\text { Radon concentration, } \\
\text { in } \mathrm{pCi} / \mathrm{L}\end{array}$}} & \multicolumn{3}{|c|}{ Indoor air } \\
\hline & & Less than 2.0 & 2.0 to 4.0 & Greater than 4.0 \\
\hline \multirow{3}{*}{ Groundwater } & Less than 300 & $\begin{array}{l}\text { Low potential radon exposure } \\
\text { from both groundwater and } \\
\text { indoor air }\end{array}$ & $\begin{array}{l}\text { Low potential radon exposure } \\
\text { from groundwater and } \\
\text { intermediate potential radon } \\
\text { exposure from indoor air }\end{array}$ & $\begin{array}{l}\text { Low potential radon exposure } \\
\text { from groundwater and high } \\
\text { potential radon exposure from } \\
\text { indoor air }\end{array}$ \\
\hline & \multirow{2}{*}{$\begin{array}{l}300 \text { to } 4,000 \\
\text { Greater than } \\
4,000\end{array}$} & $\begin{array}{l}\text { Intermediate potential radon } \\
\text { exposure from groundwater } \\
\text { and low potential radon } \\
\text { exposure from indoor air }\end{array}$ & $\begin{array}{l}\text { Intermediate potential radon } \\
\text { exposure from both } \\
\text { groundwater and indoor air }\end{array}$ & $\begin{array}{l}\text { Intermediate potential radon } \\
\text { exposure from groundwater } \\
\text { and high potential radon } \\
\text { exposure from indoor air }\end{array}$ \\
\hline & & $\begin{array}{l}\text { High potential radon exposure } \\
\text { from groundwater and low } \\
\text { potential radon exposure from } \\
\text { indoor air }\end{array}$ & $\begin{array}{l}\text { High potential radon exposure } \\
\text { from groundwater and } \\
\text { intermediate potential radon } \\
\text { exposure from indoor air }\end{array}$ & $\begin{array}{l}\text { High potential radon exposure } \\
\text { from both groundwater and } \\
\text { indoor air }\end{array}$ \\
\hline
\end{tabular}


were overlaid with a geospatial dataset of public water-supply service areas to explore the geographic extent of areas where the population is assumed to be using domestic self-supplied water and could be at greater potential of exposure to radon from groundwater.

\section{Evaluation of Radon Occurrence in Groundwater from 16 Geologic Units}

This section of the report evaluates the distribution of radon in groundwater in 16 geologic units in Pennsylvania. Radon occurrence in groundwater was analyzed and aggregated within the study area.

The spatial distribution of 1,041 measurements of radon concentrations in groundwater sampled in the study area is shown in figure 4 . Concentrations of radon in groundwater from the 1,041 sampled wells ranged from less than the highest MRL of $80 \mathrm{pCi} / \mathrm{L}$ to $32,280 \mathrm{pCi} / \mathrm{L}$; the median concentration was $1,525 \mathrm{pCi} / \mathrm{L}$. The data have a skewness of 4.7 , indicating that the data are skewed to the right (long tail of high concentration values). About 87 percent (909) of groundwater radon concentrations were greater than or equal to the proposed EPA MCL of $300 \mathrm{pCi} / \mathrm{L}$, whereas 14 percent (150) of concentrations were greater than or equal to the proposed EPA AMCL of $4,000 \mathrm{pCi} / \mathrm{L}$.

\section{Radon Concentrations in Groundwater by Geologic Unit}

Radon concentrations in groundwater in the study area were analyzed to determine general patterns of radon concentrations among the geologic units. Concentrations of radon in groundwater in most of the geologic units were highly variable and skewed (table 3), so the units were evaluated on the basis of median radon concentration, which is the mid-point concentration at which one-half of the samples have a lower concentration and one-half have a higher concentration. The degree of skewness among the 16 geologic units ranged from $0.5 \mathrm{pCi} / \mathrm{L}$ (Peters Creek Schist; Xpc) to $4.5 \mathrm{pCi} / \mathrm{L}$ (Ledger Formation; $\mathrm{Cl}$ ) indicating that, for many geologic units, additional information might be gained from computing lognormal distributions and focusing additional analysis on the highconcentration data. For the purpose of data analysis, median radon concentrations of 300 and $4,000 \mathrm{pCi} / \mathrm{L}$ were chosen as boundary values for classifying geologic units (fig. 5) because the EPA has proposed a requirement that public water suppliers provide water with radon concentrations no higher than $4,000 \mathrm{pCi} / \mathrm{L}$ and has also proposed a requirement that, for states without enhanced indoor air programs, public water suppliers reduce radon levels in drinking water to $300 \mathrm{pCi} / \mathrm{L}$ (U.S. Environmental Protection Agency, 2011).

All of the geologic units within the study area, except for the Allegheny (Pa) and Glenshaw (Pcg) Formations, had median radon concentrations greater than $300 \mathrm{pCi} / \mathrm{L}$ (table 3 ). The Allegheny $(\mathrm{Pa})$ and Glenshaw $(\mathrm{Pcg})$ Formations, which are in the Appalachian Plateaus Physiographic Province in the western part of the State (fig. 5), had the lowest median radon concentrations of $155 \mathrm{pCi} / \mathrm{L}(\mathrm{N}=38)$ and $257 \mathrm{pCi} / \mathrm{L}(\mathrm{N}=51)$, respectively (table 3; fig. 5). Only the Peters Creek Schist $(\mathrm{Xpc})$, which is in the Piedmont Physiographic Province in southeastern Pennsylvania, had a median radon concentration $(4,300 \mathrm{pCi} / \mathrm{L} ; \mathrm{N}=51)$ greater than the EPA proposed $\mathrm{AMCL}$ of $4,000 \mathrm{pCi} / \mathrm{L}$ (table 3; fig. 5). All samples from the Peters Creek Schist $(\mathrm{Xpc})$ had radon concentrations in groundwater exceeding the EPA proposed MCL of $300 \mathrm{pCi} / \mathrm{L}$ (table 3). The Peters Creek Schist also had the highest percentage (55 percent) of samples with radon concentrations in groundwater exceeding the EPA proposed AMCL of 4,000 $\mathrm{pCi} / \mathrm{L}$. The geologic unit with the most samples (175), Chickies Formation $(\mathrm{Cch})$, had a median radon groundwater concentration of $2,019 \mathrm{pCi} / \mathrm{L}$. The Chickies Formation (Cch), which consists of conglomerate, quartzite, and slate, also had the highest radon concentration from a single sample $(32,280 \mathrm{pCi} / \mathrm{L}$; Senior and Vogel, 1995).

Overall, the highest radon concentrations measured were in groundwater in the schists, gneisses, and quartzites of geologic units in the Piedmont Physiographic Province of southeastern Pennsylvania (figs. 1 and 5). This is consistent with findings reported by previously conducted studies. Senior (1998) concluded radon concentrations in groundwater in schists, quartzites, and gneisses were generally greater than radon concentrations in groundwater in anorthosite, carbonates, and ultramafic rocks. Chapman and others (2013) also determined that regionally, radon concentrations in groundwater in granites, schists, and gneisses were generally greater than those in groundwater in other bedrock types extending from New Jersey and Pennsylvania in the north to Alabama in the south. Aerial gamma-ray data also indicated relatively elevated uranium concentrations in aquifer materials of some of these same felsic rocks in Pennsylvania (table 1) and throughout bedrock types within the Piedmont Physiographic Province extending from New Jersey and Pennsylvania in the north to Alabama in the south (Chapman and others, 2013). 

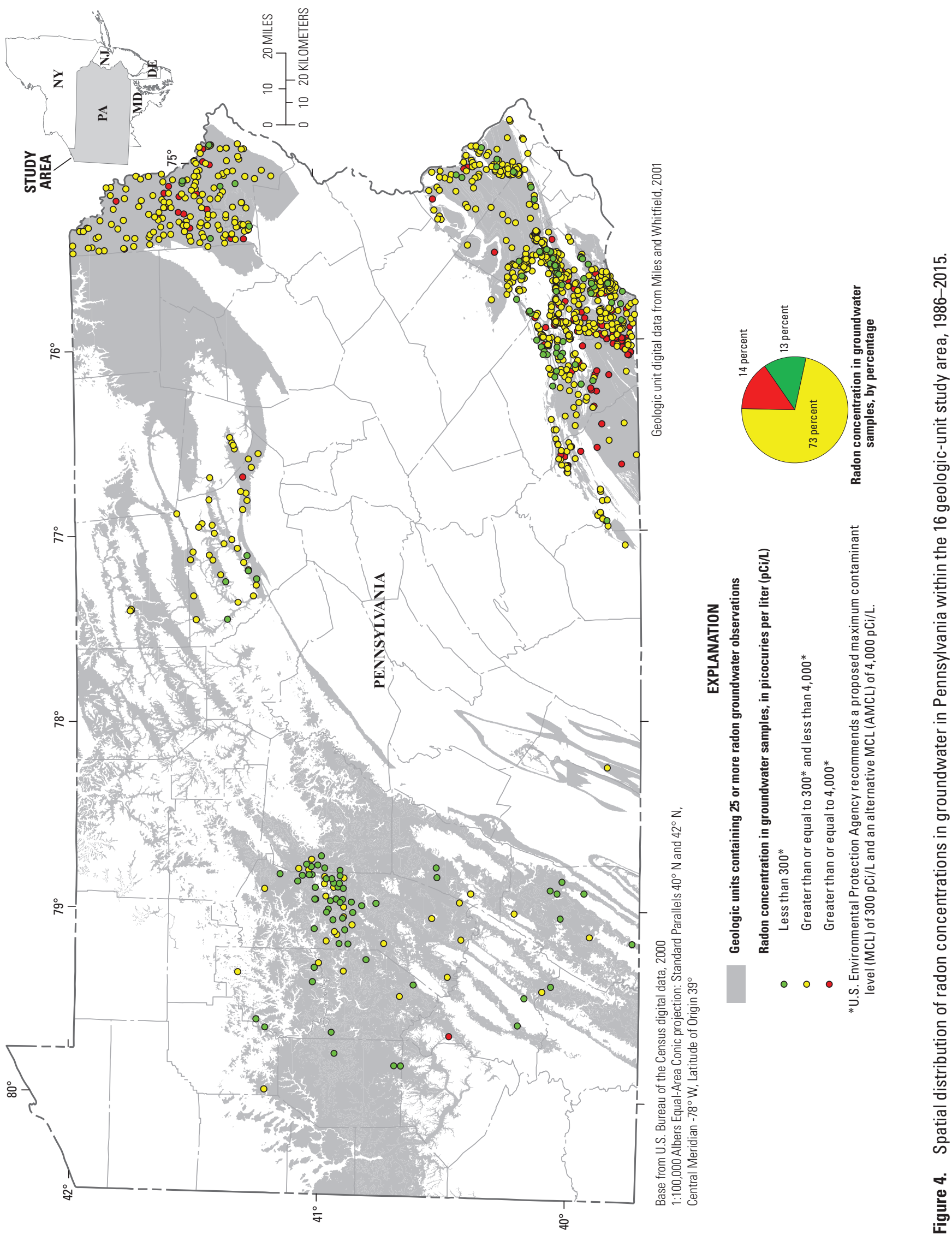


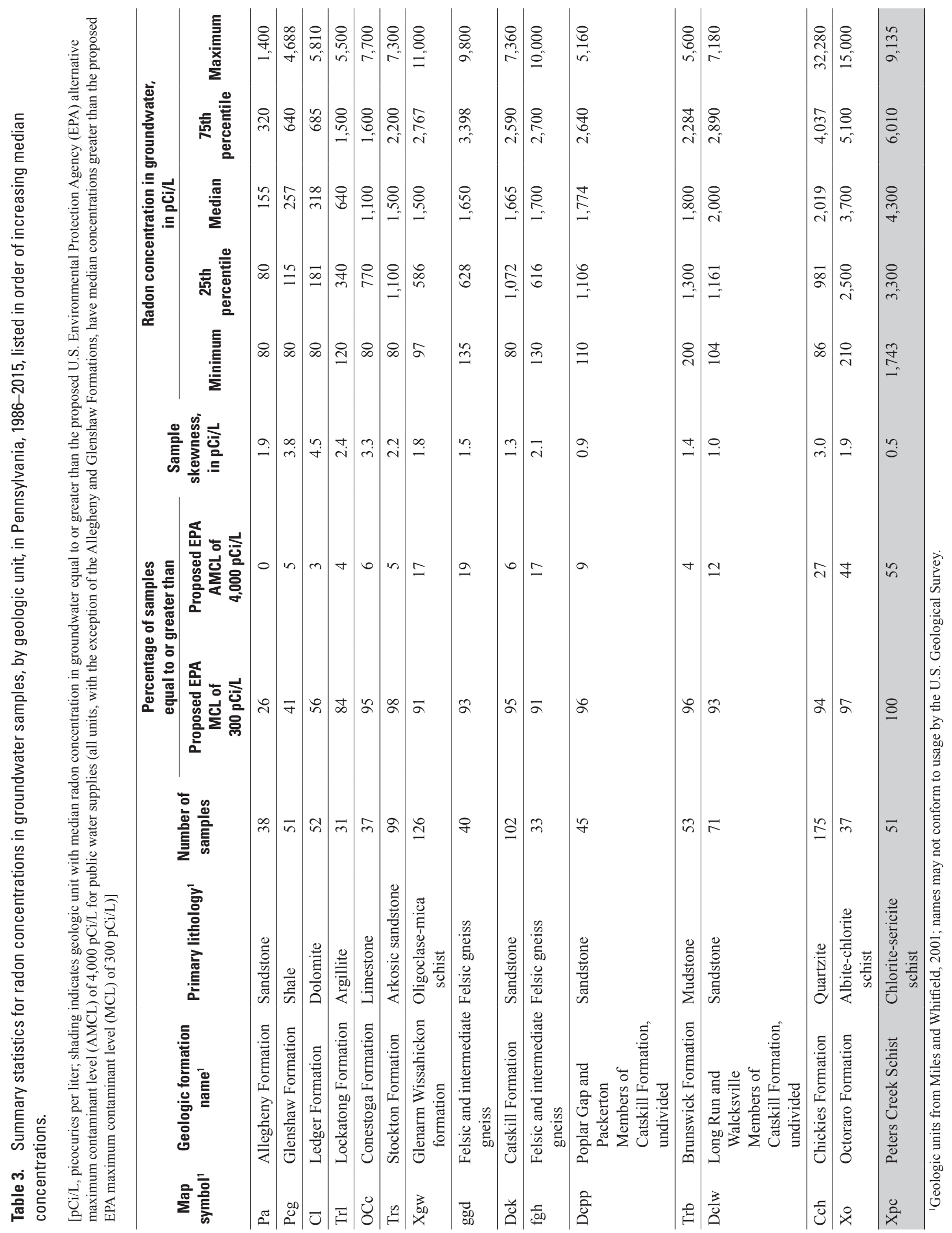




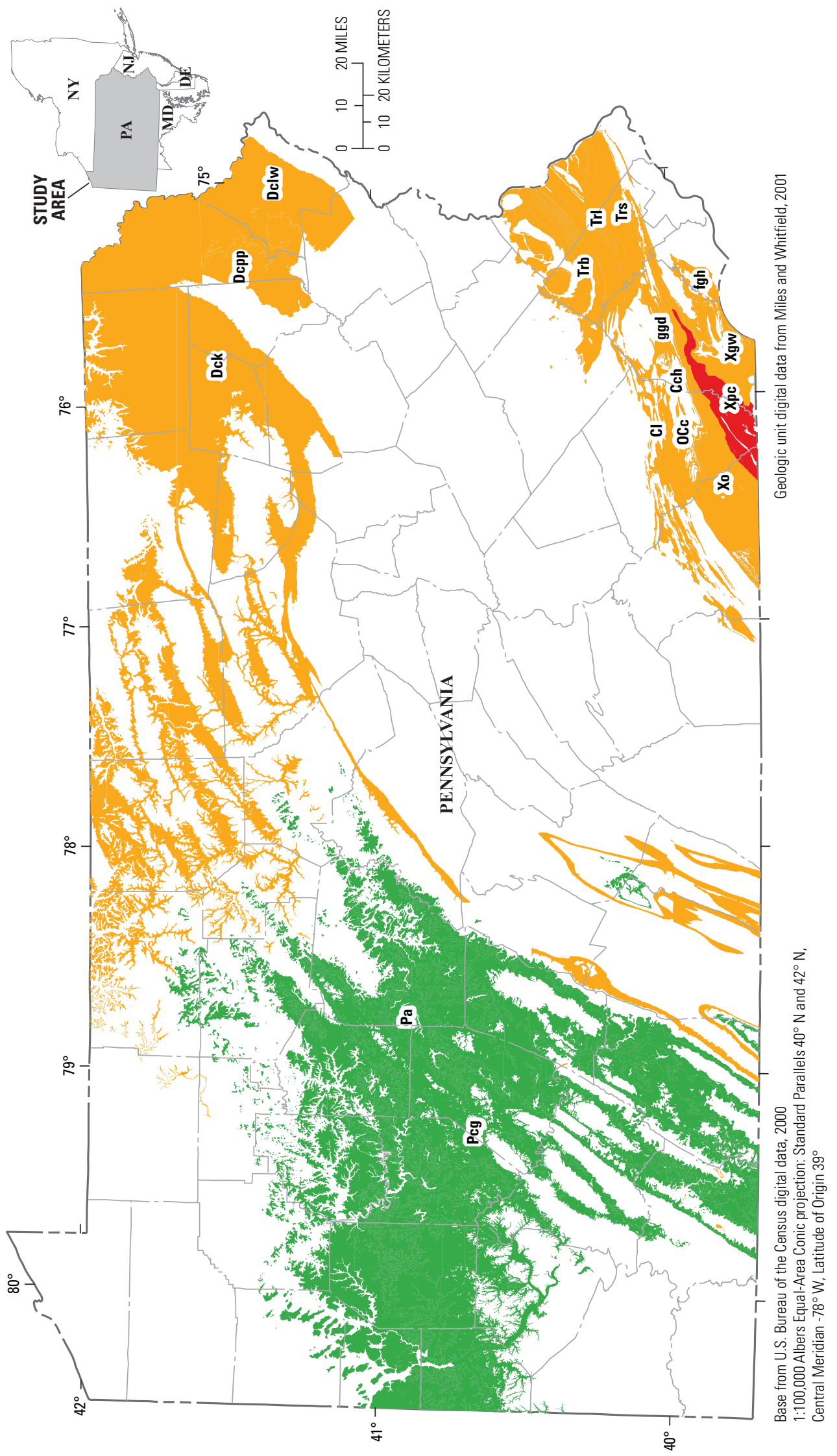




\section{Potential Radon Exposure from Groundwater and Indoor Air}

This section of the report documents variations in radon concentrations in groundwater and indoor air in the 16 geologic units and classifies potential radon exposure from groundwater and indoor air determined from classification of geologic units by median radon concentrations according to proposed and recommended regulatory limits.

\section{Variations in Radon Concentrations in Groundwater and Indoor Air by Geologic Unit}

Variations in concentrations of radon in groundwater and indoor air among geologic units were examined using graphical plots and statistical tests. Boxplots of radon concentrations in groundwater and indoor air, grouped according to geologic unit, are presented in figure 6 with Tukey groups indicated. The boxplots in figures $6 A$ and $6 B$ are sorted from highest to lowest by radon in groundwater Tukey group (fig. $6 A$ ). Because the Tukey test groups data with respect to mean concentrations and the radon in groundwater boxplots (fig. 6A) are sorted by radon in groundwater Tukey group, the order may differ slightly between the boxplots in figure $6 \mathrm{~A}$ and the table containing summary statistics (table 3 ), which has geologic units listed in order of increasing median concentrations.

Median concentrations of radon in groundwater range from $155 \mathrm{pCi} / \mathrm{L}$ in the Allegheny Formation $(\mathrm{Pa})$ to $4,300 \mathrm{pCi} / \mathrm{L}$ in the Peters Creek Schist (Xpc), whereas median concentrations of radon in indoor air range from $2.1 \mathrm{pCi} / \mathrm{L}$ in the Felsic and intermediate gneiss (fgh) to $6.4 \mathrm{pCi} / \mathrm{L}$ in the Peters Creek Schist (Xpc). Median concentrations of radon in groundwater and indoor air were determined to differ significantly among the 16 geologic units (Kruskal-Wallis test, probability, $\mathrm{p}<0.001)$. A simultaneous pairwise significance test (Tukey) was used to further investigate patterns among the geologic units. The Tukey test indicated that groundwater in the Peters Creek Schist (Xpc) had significantly higher concentrations of radon than the groundwater in the other geologic units (fig. 6) and had the highest median concentration. The Octoraro (Xo) and Chickies (Cch) Formations had the second and third highest median radon concentrations in groundwater and were not statistically distinguishable from the Peters Creek Schist (Xpc). Radon concentrations in groundwater were significantly lower in the Allegheny Formation (Pa) than in these high-radon formations, and this unit also had the lowest median groundwater concentration (fig. 6). The Tukey's test indicated that radon concentrations in groundwater from the remaining units had a median value between the other defined high and low concentration units, and the intermediate concentration distributions could not be statistically distinguished from one another. The Tukey's test also indicated that radon concentrations in indoor air were significantly higher in the Peters Creek Schist (Xpc) than in the other geologic units. The Tukey's test indicated that the Peters Creek Schist (Xpc) had the highest radon concentrations in indoor air and the Octoraro Formation (Xo) had the second highest. The Octoraro Formation (Xo) also had among the highest median radon concentrations in groundwater, slightly below $4,000 \mathrm{pCi} / \mathrm{L}$. The radon concentrations in indoor air were significantly lower in the Felsic and intermediate gneiss (fgh) than in most other, but not all, geologic units.

Generally, the geologic units with statistically higher radon concentrations in groundwater include schists and gneisses, whereas units with statistically lower radon concentrations in groundwater include dolomites and sandstones (fig. 6; table 3). This is consistent with previously published studies regarding radon concentrations in groundwater in Pennsylvania. Senior (1998) describes statistically higher radon concentrations in groundwater in schists and gneisses and statistically lower radon concentrations in groundwater in dolomites. Lindsey and Ator (1996) also report lower radon concentrations in groundwater in dolomites than in the schists and gneisses observed by Senior (1998). In addition, the percentage of near-surface land area with elevated equivalent uranium concentrations for the sandstones of the Allegheny Formation ( $\mathrm{Pa} ; 18$ percent) was not as high as for the Peters Creek schist (Xpc; 59 percent) or Octoraro Formation (Xo; 67 percent) in southeastern Pennsylvania (table 1). In particular, Senior (1998) reports that radon concentrations in groundwater in the geologic units studied, such as the Peters Creek Schist (Xpc), are indicative of the uranium content of aquifer materials.

\section{Classification of Potential Radon Exposure from Groundwater and Indoor Air by Geologic Unit}

Median radon concentrations in groundwater for the 16 geologic units were compared to associated median indoor air radon concentrations (Gross, 2013) and areas served by public water-supply systems (Pennsylvania Department of Environmental Protection, 2013) to further refine the understanding of potential radon exposure from indoor air and groundwater. Median groundwater and indoor air radon concentrations were used to classify potential radon exposure from groundwater and indoor air to create classifications containing geologic units that had similar potential radon exposure (table 4). These classifications were then compared to a geospatial dataset of public water-supply service areas.

Figure 7 depicts potential radon exposure classifications for the geologic units with public water-supply service areas overlaid as crosshatched diagonal lines. The potential radon exposure classifications are listed in table 4 with median radon concentrations in groundwater and indoor air and the calculated percentage of the population within each geologic unit assumed to be using self-supplied water. The Allegheny ( $\mathrm{Pa}$ ) and Glenshaw (Pcg) Formations in the Appalachian Plateaus Physiographic Province had median radon concentrations in groundwater of less than $300 \mathrm{pCi} / \mathrm{L}$ and median concentrations in indoor air between 2.0 and $4.0 \mathrm{pCi} / \mathrm{L}$, indicating that these two units had low potential radon exposure from groundwater 


\section{A. Groundwater}

Tukey group

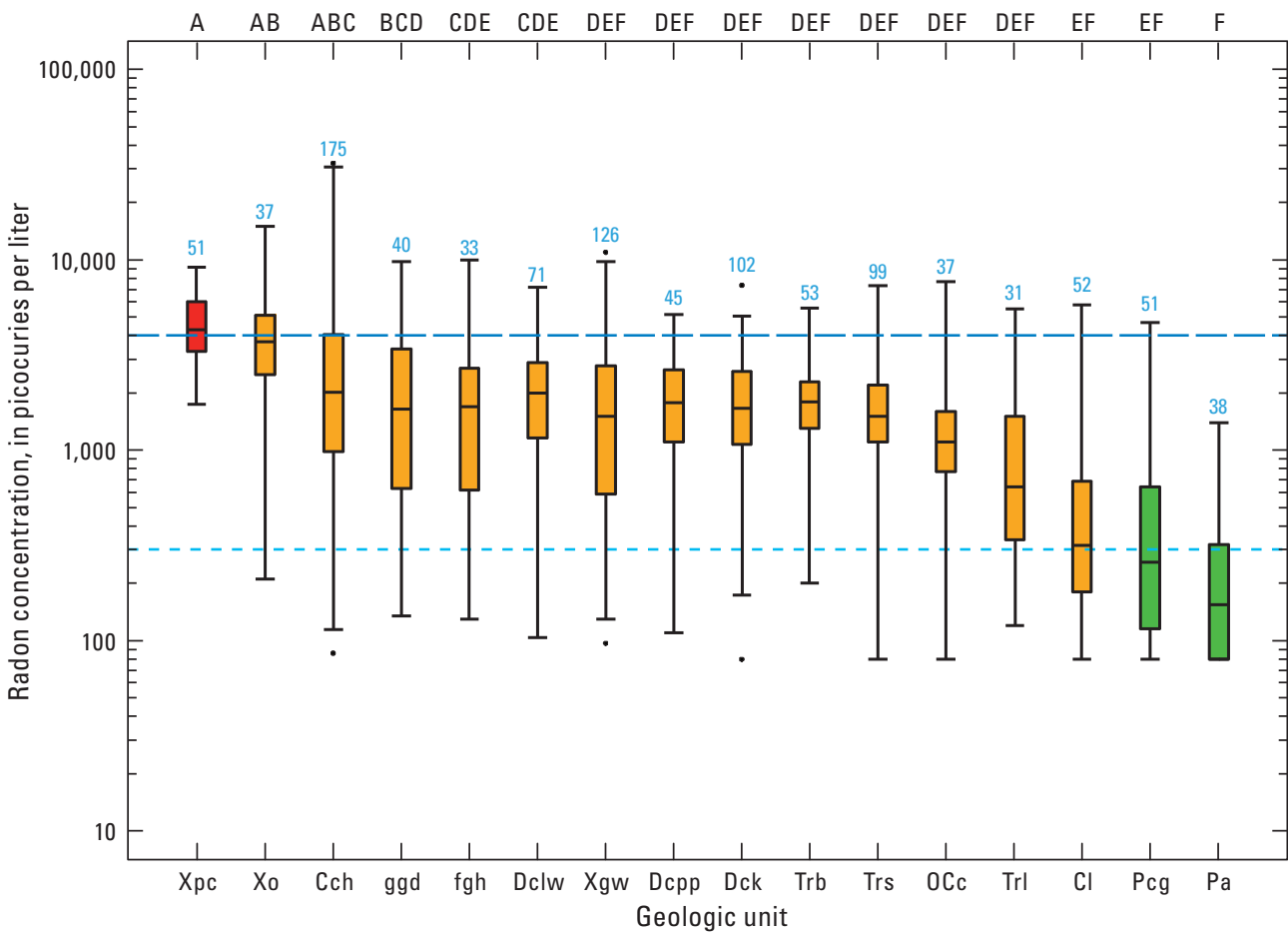

EXPLANATION

Number of observations

All observations greater than 99th percentile

99th percentile

75th percentile

Median

25th percentile

1st percentile

- All observations less than 1st percentile

Median radon concentrations in groundwater, in picocuries per liter (pCi/L)

Less than $300^{*}$

Greater than or equal to $300^{*}$ and less than $4,000^{*}$

Greater than or equal to $4,000^{*}$

- U.S. Environmental Protection Agency (EPA) proposed alternative maximum contaminant level (AMCL)

EPA proposed maximum contaminant level (MCL)

*EPA recommends a proposed $\mathrm{MCL}$ of $300 \mathrm{pCi} / \mathrm{L}$ and an AMCL of $4,000 \mathrm{pCi} / \mathrm{L}$

for public water-supply systems

\section{B. Indoor air Tukey group}

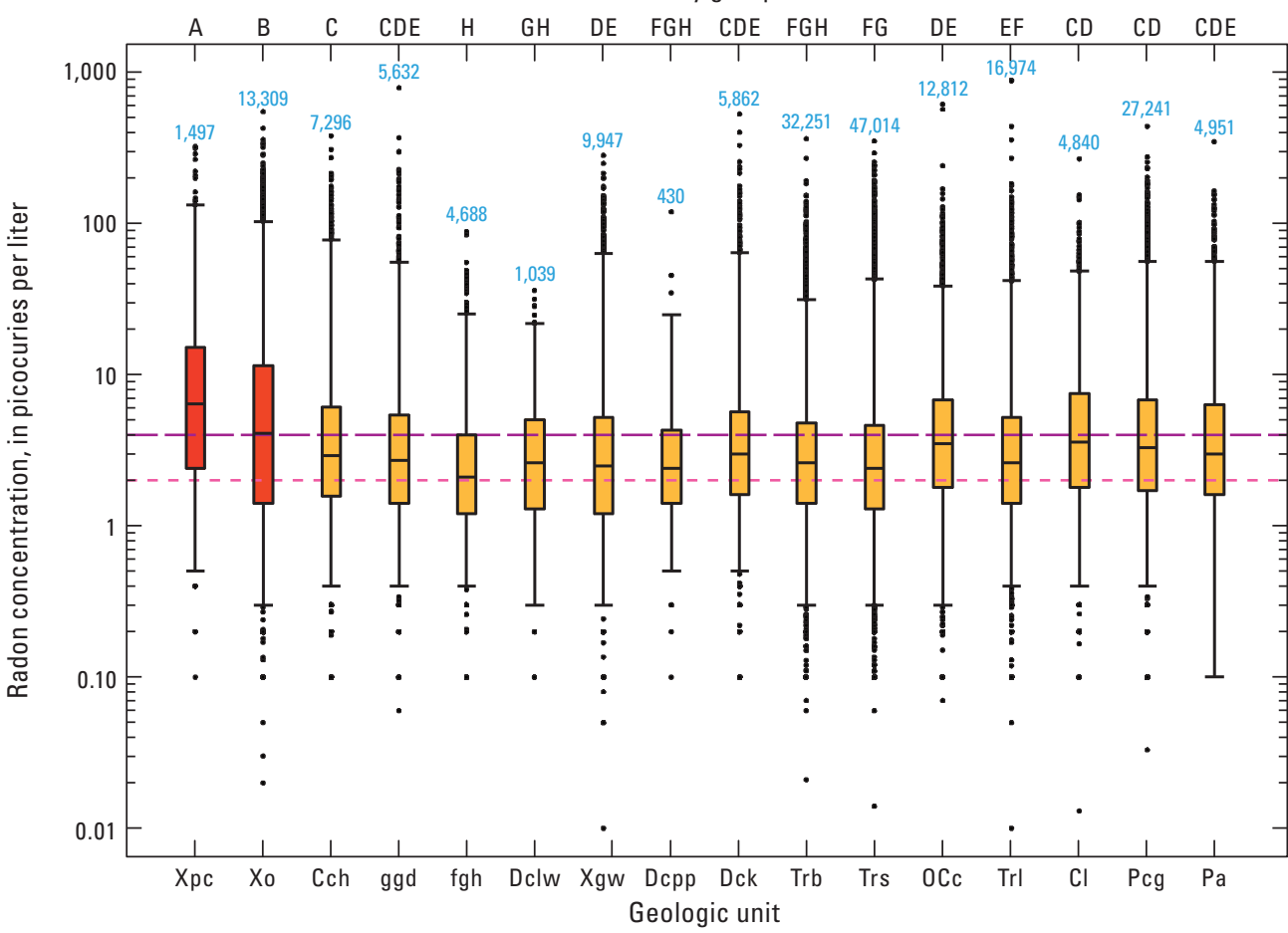

\section{EXPLANATION}

430 Number of observations

- All observations greater than 99th percentile

99th percentile

75th percentile

Median

25th percentile

1st percentile

- All observations less than 1st percentile

Median radon concentrations in indoor air, in picocuries per liter (pCi/L)

Greater than or equal to $2.0^{*}$ and less than $4.0^{*}$

Greater than or equal to $4.0^{*}$

U.S. Environmental Protection Agency (EPA) recommends taking action to mitigate if radon concentration is $4.0 \mathrm{pCi} / \mathrm{L}$ or more

EPA recommends considering mitigation for radon concentrations of 2.0 to $3.9 \mathrm{pCi} / \mathrm{L}$

*EPA recommends considering mitigation for concentrations of 2.0 to $3.9 \mathrm{pCi} / \mathrm{L}$ and taking action to mitigate if the concentration is

$4.0 \mathrm{pCi} / \mathrm{L}$ or more

Figure 6. Distribution of radon concentrations in $A$, groundwater and $B$, indoor air for 16 geologic units in Pennsylvania, $1986-2015$. (Tukey groups are represented by letters $\mathrm{A}$ through $\mathrm{H}$; geologic units in group A have the highest median concentration rank, whereas geologic units in groups $\mathrm{B}$ through $\mathrm{H}$ have successively lower median concentration ranks. Geologic units that have letters in common do not differ significantly from one another. Geologic unit abbreviations are explained in tables 1 and 3.) 


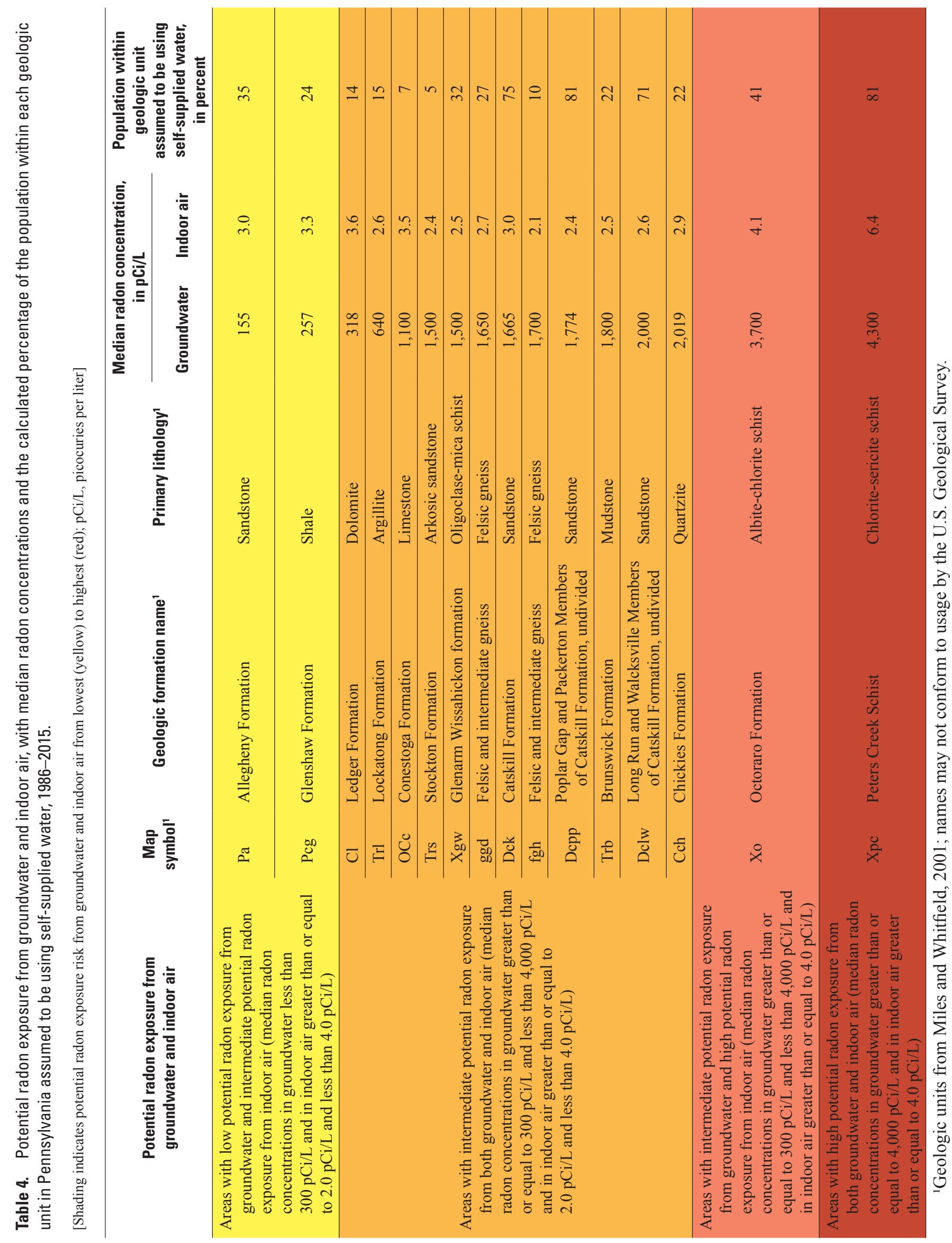



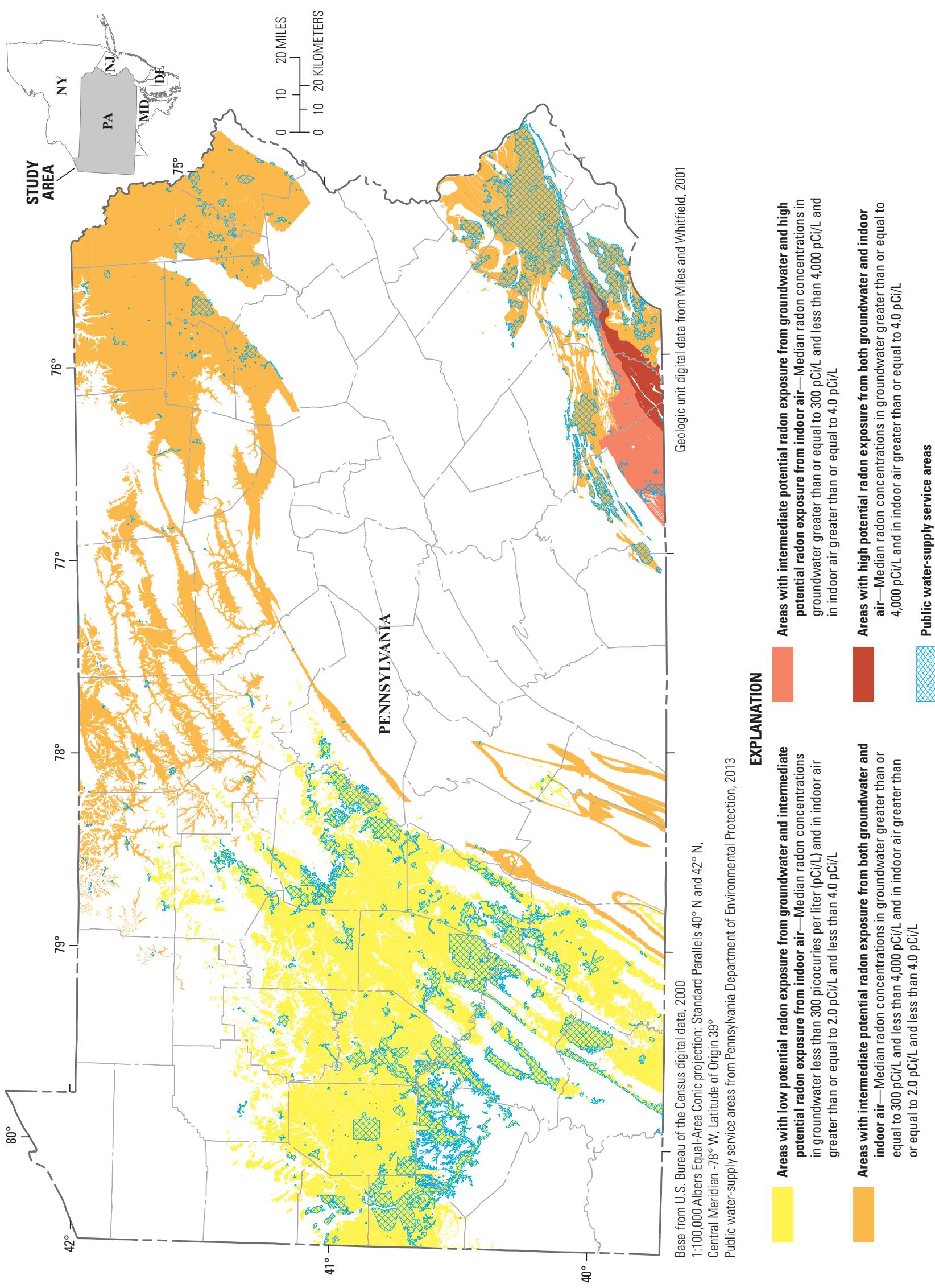

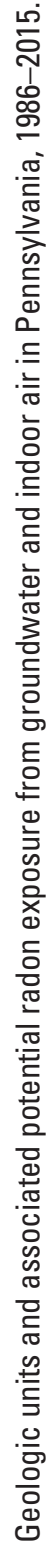

产 
and intermediate potential radon exposure from indoor air. In this study, these two geologic units are classified as having the lowest potential of total radon exposure (total being the sum of water-sourced and air-sourced exposure). All other geologic units, except for the Octoraro Formation (Xo) and Peters Creek Schist (Xpc), are considered to have intermediate potential radon exposure from both groundwater and indoor air, which means they had median radon concentrations in groundwater between $300 \mathrm{pCi} / \mathrm{L}$ and $4,000 \mathrm{pCi} / \mathrm{L}$ and median radon concentrations in indoor air between $2.0 \mathrm{pCi} / \mathrm{L}$ and $4.0 \mathrm{pCi} / \mathrm{L}$. The Octoraro Formation (Xo) in the Piedmont Physiographic Province is considered an area with intermediate potential radon exposure from groundwater (radon concentrations in groundwater between $300 \mathrm{pCi} / \mathrm{L}$ and $4,000 \mathrm{pCi} / \mathrm{L}$ ) and high potential radon exposure from indoor air (radon concentrations in indoor air greater than or equal to $4.0 \mathrm{pCi} / \mathrm{L})$. The Peters Creek Schist (Xpc), also in the Piedmont Physiographic Province, has high potential radon exposure from both groundwater and indoor air with radon concentrations in groundwater greater than or equal to $4,000 \mathrm{pCi} / \mathrm{L}$ and concentrations in indoor air greater than or equal to $4.0 \mathrm{pCi} / \mathrm{L}$.

An overlay of public water-supply service areas in figure 7 shows those areas assumed to have low potential radon exposure in groundwater are present mostly in western Pennsylvania, and those areas assumed to have intermediate and highest potential radon exposure in groundwater are present in eastern Pennsylvania. People living outside of the public water-supply service areas are assumed to use groundwater supplied by domestic self-supply wells and, therefore, are most likely to be exposed to radon released from the groundwater because the water is used almost immediately (little to no storage) giving radon little chance to diminish through radioactive decay, as might be the case for a large public supply system. In such areas, outreach efforts need to be focused on individual well owners instead of public watersupply managers, making assessment of available data all the more important.

The geologic unit with the highest potential radon exposure from both groundwater and indoor air is the Peters Creek Schist (Xpc) (fig. 7). Groundwater within the Peters Creek Schist (Xpc) has a radon concentration range of 1,743 to $9,135 \mathrm{pCi} / \mathrm{L}$, which corresponds to estimated contributions to indoor air of 0.2 to $0.9 \mathrm{pCi} / \mathrm{L}$, based on exchange ratios of 10,000:1 for water:air developed by Prichard (1987). Although the magnitude of these contributions from the groundwater is relatively low, 81 percent (table 4 ) of the population living on the Peters Creek Schist outcrop relies on groundwater supplied by domestic self-supply wells. This same population also has the greatest potential for exposure to radon from indoor air among populations for all the geologic units tested because concentrations that exceed the EPA advisory level of $4.0 \mathrm{pCi} / \mathrm{L}$ likely occur in more than 50 percent of residences and the median concentration exceeds the advisory level of $4.0 \mathrm{pCi} / \mathrm{L}$. For this population, the radon concentration in groundwater may be a notable contributor to the high radon concentrations in indoor air.

\section{Limitations and Uses of Radon Data}

The geospatial data, such as radon concentrations in groundwater and indoor air, geologic units, and public water-supply service areas, used to create the maps shown in figures 5 and 7 have limitations. Aggregated indoor air radon data have spatial accuracy limitations (imprecise geocoding accuracy), whereas the associated geologic unit and data from the public water supplier's service area have spatial and interpretation accuracy limitations (broad interpretation of geologic units, data accuracy scale). For example, geocoding scores associated with radon test results for indoor air, despite having the maximum confidence scores (100 out of 100), could be spatially variable by as much as 700 feet, so some number of test results may be aggregated incorrectly into geologic units that do not represent the presumed underlying geology (Gross, 2013). In addition, there is inherent error in the original Pennsylvania geologic unit dataset created by Miles and Whitfield (2001) because the dataset is compiled at a 1:250,000 scale, representing a broad interpretation of the spatial distribution of geologic units across the State. More precise mapping designed to minimize bias and maximize use of key geological factors for delineating units is desirable (Miles, 1998). The radon concentration distribution in groundwater in some geologic units may be better represented if the units are separated into, and evaluated as, several subunits and listed in different classifications of severity as warranted. For example, the Catskill Formation (Dck), which is already the largest of the geologic units $\left(4,515 \mathrm{mi}^{2}\right.$; table 1$)$, is also represented by the Long Run and Walcksville Members of Catskill Formation, undivided (Dclw) and the Poplar Gap and Packerton Members of Catskill Formation, undivided (Dcpp), but this large unit could be further divided for evaluation into subunits to determine whether one subunit may have significantly higher radon concentrations in groundwater than the other. Also, the boundaries of a public water supplier's service area are approximate. Even though it may appear in figure 7 that a given area is within a public water supplier's boundary, the spatial data were not verified in the field, but such verification may be necessary to obtain improvement in accuracy.

Maps showing median radon concentrations in groundwater according to geologic unit and potential radon exposure from groundwater and indoor air are shown in figures 5 and 7. These maps show data only for the 16 geologic units in Pennsylvania in which 25 or more radon groundwater samples were collected. Considering that Pennsylvania has a total of 188 recognized geologic units, of which the 16 included in this study only account for 31 percent of Pennsylvania's total land area, there are large data gaps across the State. These data gaps are especially apparent in the northern, south-central, and central parts of Pennsylvania where less than 25 radon samples were collected per geologic unit. Many of these areas have a relatively low population density, but a large percentage of that population is being served by domestic self-supplied water. As a result, there is a need for collection of additional radon in groundwater samples to more accurately characterize 
potential radon exposure in Pennsylvania, including that from groundwater. Of the 172 geologic units containing insufficient data, 82 geologic units (68 percent) had 1-10 radon in groundwater samples, whereas 22 geologic units (18 percent) had 10-24 radon in groundwater samples. Future sampling efforts could focus on collecting 1-15 radon in groundwater samples in the 22 geologic units with 10-24 radon in groundwater samples so that these geologic units can be included in future studies and data gaps will be filled for an additional 18 percent of the State.

The data gap in the central part of Pennsylvania represents the locations of most of the 630 sampled wells excluded from the study owing to well locations within geologic units associated with insufficient (less than 25) radon groundwater sample data. This area of the State is part of the Ridge and Valley Physiographic Province, known for narrow geologic units that are a result of heavy folding and fracturing; thus, owing to the narrow size of these geologic units and lack of past studies focused on dedicated sampling within a specific geologic unit, there were not enough data for any of these units to be included. It was beyond the scope of this study to combine similar geologic units within the Ridge and Valley Physiographic Province to reach the data threshold of 25 groundwater samples with radon concentrations.

Additionally, this study considers all wells to be completed in the geologic unit that the well point intersects, which is determined on the basis of the bedrock geology map of Pennsylvania (Miles and Whitfield, 2001), rather than attempting to separate or remove from the data wells completed in glacial aquifers. As a result, this study does not account for the fact that some wells may be completed in glacial materials and some houses may be built on glacial sand deposits in the northern part of the Appalachian Plateaus Physiographic Province. Thus, the radon-occurrence statistics for geologic units in the northern part of the Appalachian Plateaus Physiographic Province (Catskill Formation [Dck], Long Run and Walcksville Members of Catskill Formation, undivided [Dclw], and Poplar Gap and Packerton Members of Catskill Formation, undivided [Dcpp]) may not be completely representative of the geologic units in the western part (Allegheny [Pa] and Glenshaw [Pcg] Formations) (fig. 1). Radon gas is especially mobile in coarse glacial formations (Gundersen and Smoot, 1993), and this may explain why the northern geologic units in the Appalachian Plateaus Physiographic Province resulted in higher potential radon exposure from groundwater and indoor air than the geologic units in the western part of the physiographic province (fig. 7).

The maps in figures 5 and 7 show median concentrations of radon in groundwater to classify radon exposure within geologic units. However, radon concentrations vary widely within the geologic units, even among those that have median radon concentrations in groundwater less than the EPA proposed MCL or AMCL (fig. 6). Radon concentrations in indoor air and groundwater have been shown to vary temporally, and the concentrations can be affected by large numbers of factors that also can vary considerably (Gunderson and Smoot, 1993;
De Francesco and others, 2010). It is because uranium concentrations of some geologic units are much higher than those of other geologic units, and because the radon concentration in soil gas and groundwater generally co-vary proportionately with the uranium content, that radon concentrations in soil gas and groundwater can be distinguished among many geologic units (Wanty and others, 1992; Chapman and others, 2013). It is presumed that the sample size of 25 or more can result in a reasonably reproducible median radon concentration for the geologic units because of this strong co-variation with uranium content, but the overall distribution is unlikely to be defined or reproducible without the collection of a larger dataset. Consequently, the maps (figs. 5 and 7) are not intended to be used to predict radon concentrations at specific sites or to be used as a decision-making tool for property owners to decide whether to test for radon concentrations at specific property locations. The data are intended to facilitate potential radon exposure awareness and point out data gaps throughout Pennsylvania. By gaining understanding of the distribution of radon concentrations in groundwater and indoor air among geologic units, those units with the highest median and maximum radon concentrations in groundwater and indoor air can be identified (fig. 6), facilitating awareness for those persons with the greatest potential radon exposure.

Scientific information describing potential radon exposure determined by median radon concentrations in groundwater and indoor air within geologic units in Pennsylvania provides health officials with decision-making tools that can be used to enhance and protect quality of life. Health officials can prioritize and conduct additional studies in areas within the State that have the overlap of the highest potential radon exposure and the greatest percentage of the population using self-supplied water to determine which areas with high potential radon exposure have high occurrence of specific health issues through ecological-level analyses or epidemiological studies. This information can be used to raise awareness and direct resources towards areas of concern to maximize risk remediation and can be included as a functional layer within a public portal designed to inform Pennsylvania's citizens of possible environmental risks to human health. The maps derived from the radon concentration data can be used as tools for resource decision-making and may also have value for ecological-level analysis of disease outcomes. These maps are intended to be available through databases of the Centers for Disease Control and the Pennsylvania Environmental Public Health Tracking programs that are available on the Internet (http://doh.pa.gov/epht).

\section{Summary and Conclusions}

In a study conducted by the U.S. Geological Survey, in cooperation with the Pennsylvania Department of Health and the Pennsylvania Department of Environmental Protection, radon occurrence was evaluated in 1,041 groundwater 
samples collected during 1986-2015 from 16 geologic units in Pennsylvania with 25 or more radon in groundwater samples. Radon concentrations in groundwater greater than or equal to the proposed U.S. Environmental Protection Agency (EPA) maximum contaminant level (MCL) of 300 picocuries per liter $(\mathrm{pCi} / \mathrm{L})$ were present in 87 percent of the samples, whereas concentrations greater than or equal to the proposed alternative $\mathrm{MCL}(\mathrm{AMCL})$ of $4,000 \mathrm{pCi} / \mathrm{L}$ were present in 14 percent of the samples. The highest radon concentration in groundwater was $32,280 \mathrm{pCi} / \mathrm{L}$ in a sample from the Chickies Formation $(\mathrm{Cch})$ in the Piedmont Physiographic Province of southeastern Pennsylvania.

Data on groundwater samples were aggregated according to the 16 geologic units in Pennsylvania to identify units with median radon concentrations in groundwater greater than $300 \mathrm{pCi} / \mathrm{L}$ and 4,000 pCi/L, the MCL and AMCL, respectively. Graphical plots and statistical tests were used to determine variations in radon concentrations in groundwater and indoor air. All of the geologic units, except for the Allegheny (Pa) and Glenshaw (Pcg) Formations in the western part of the Appalachian Plateaus Physiographic Province, had median radon concentrations greater than the proposed EPA MCL of $300 \mathrm{pCi} / \mathrm{L}$. Only one geologic unit, the Peters Creek Schist (Xpc) in the Piedmont Physiographic Province, had a median radon concentration greater than the EPA proposed AMCL of $4,000 \mathrm{pCi} / \mathrm{L}$. Median concentrations of radon in groundwater and indoor air were determined to differ significantly (Kruskal-Wallis test, $\mathrm{p}<0.001$ ) among the 16 geologic units. Tukey's test indicated that radon concentrations in groundwater and indoor air in the Peters Creek Schist (Xpc) were significantly higher than those in the other geologic units.

Median radon concentrations in groundwater for the 16 geologic units were compared to associated median indoor air radon concentrations and areas served by public watersupply systems to classify potential radon exposure from indoor air and groundwater. The Peters Creek Schist (Xpc) outcrop was determined to be the area with highest potential of radon exposure from groundwater and indoor air; the Peters Creek Schist (Xpc) is associated with median radon concentrations in groundwater greater than or equal to $4,000 \mathrm{pCi} / \mathrm{L}$ and median radon concentrations in indoor air greater than or equal to $4.0 \mathrm{pCi} / \mathrm{L}$, the highest contributions from groundwater and indoor air. The Octoraro Formation (Xo) outcrop in the Piedmont Physiographic Province had high potential radon exposure from indoor air, but potential radon exposure from groundwater was somewhat less than that for the Peters Creek Schist (Xpc) outcrop. The median radon concentration in groundwater from the Octoraro Formation (Xo) was between $300 \mathrm{pCi} / \mathrm{L}$ and $4,000 \mathrm{pCi} / \mathrm{L}$, and the median radon concentration in indoor air was greater than or equal to $4.0 \mathrm{pCi} / \mathrm{L}$. The Allegheny (Pa) and Glenshaw (Pcg) Formations were determined to have the lowest potential of total radon exposure with median radon concentrations in groundwater less than $300 \mathrm{pCi} / \mathrm{L}$ and median radon concentrations in indoor air between 2.0 and $4.0 \mathrm{pCi} / \mathrm{L}$. The concentrations in indoor air were generally less than the current recommended standard for indoor air, and the potential radon exposure contribution from groundwater source was low.

In addition, the Peters Creek Schist (Xpc), which was determined to have the highest potential of radon exposure from groundwater and indoor air, also has one of the highest percentages of population assumed to be using self-supplied water (81 percent). Water from domestic self-supply wells is likely to have the greatest variability in radon concentrations, including the most extreme concentrations. In such areas, outreach efforts need to be focused on individual well owners instead of public water-supply managers, making assessment of available data all the more important. Outreach efforts can include informing citizens that the main risk to human health from radon in water is associated with inhalation when radon degases from water into indoor air with exposure to radon in groundwater primarily occurring through ingestion by drinking the water or inhalation of radon that has been released from the water during household activities (showering, washing clothes, or washing dishes) when the water is heated or agitated.

For every $10,000 \mathrm{pCi} / \mathrm{L}$ of radon in water, it is estimated that about $1 \mathrm{pCi} / \mathrm{L}$ is released to the air. Therefore, the groundwater from the Peters Creek Schist (Xpc) could be contributing $0.2-0.9 \mathrm{pCi} / \mathrm{L}$ to radon concentrations in indoor air because this unit contained a minimum radon concentration in groundwater of $1,743 \mathrm{pCi} / \mathrm{L}$ and maximum of $9,135 \mathrm{pCi} / \mathrm{L}$. For the 81 percent of the population residing on the outcrop of this geologic unit that is assumed to use self-supplied well water, the radon concentration in groundwater may be a notable contributor to the high radon concentrations in indoor air and potential risk to human health.

Potential radon exposure, determined by median radon concentrations in groundwater and indoor air for geologic units in Pennsylvania, is useful for raising awareness and directing resources towards areas of concern. These data, however, are not intended to be used to predict radon concentrations at specific sites or as a decision-making tool for property owners to decide whether to test for radon concentrations at specific property locations. Aggregated indoor radon data have spatial accuracy limitations (imprecise geocoding accuracy), whereas the associated geologic unit and public water supplier's service area data have spatial and interpretation accuracy limitations (broad interpretation of geologic units, data accuracy scale). The resulting data and maps are intended to facilitate awareness of potential radon exposure risk, provide information to assist in prioritization of resources or public-information campaigns, and point out data gaps throughout Pennsylvania. 


\section{References Cited}

Bernhardt, G.P., and Hess, C.T., 1996, Acute exposure from 222Rn and aerosols in drinking water: Environment International, v. 22, supp. 1, p. S753-S759.

Chapman, M.J., Cravotta, C.A., III, Szabo, Zoltan, and Lindsey, B.D., 2013, Naturally occurring contaminants in the Piedmont and Blue Ridge crystalline-rock aquifers and Piedmont Early Mesozoic basin siliciclastic-rock aquifers, eastern United States, 1994-2008: U.S. Geological Survey Scientific Investigations Report 2013-5072, 74 p.

De Francesco, S., Tommasone, F.P., Cuoco, E., Verrangia, G., and Tedesco, D., 2010, Radon hazard in shallow groundwaters: Amplification and long term variability induced by rainfall: Science of the Total Environment, v. 408, p. 779-789.

Duval, J.S., Carson, J.M., Holman, P.B., and Darnley, A.G., 2005, Terrestrial radioactivity and gamma-ray exposure in the United States and Canada: U.S. Geological Survey Open-File Report 2005-1413, data files, http://pubs.usgs. gov/of/2005/1413/.

Folger, P.F., Nyberg, Philip, Wanty, R.B., and Poeter, Eileen, 1994, Relationships between 222Rn dissolved in ground water supplies and indoor 222Rn concentrations in some Colorado Front Range houses: Health Physics, v. 67, p. 245-253.

Gross, E.L., 2013, Distribution of indoor radon concentrations in Pennsylvania, 1990-2007: U.S. Geological Survey Scientific Investigations Report 2013-5143, 31 p., http://pubs. usgs.gov/sir/2013/5143/.

Gross, E.L, 2017, PaRadonGW.shp - Evaluation of radon occurrence in groundwater from 16 geologic units in Pennsylvania, 1986-2015, with application to potential radon exposure from groundwater and indoor air: U.S. Geological Survey data release, https://doi.org/10.5066/F7PR7T74.

Gross, E.L., and Cravotta, C.A., III, 2017, Groundwater quality for 75 domestic wells in Lycoming County, Pennsylvania, 2014: U.S. Geological Survey Scientific Investigations Report 2016-5143, 74 p., https://doi.org/10.3133/ sir20165143.

Gundersen, L.C.S., and Smoot, J.P., 1993, Preliminary geologic radon potential assessment of Pennsylvania, in Shumann, R.R., ed., Geologic radon potential of EPA Region 3: U.S. Geological Survey Open-File Report 93-292-C, p. 105-145.

Helsel, D.R., and Hirsch, R.M., 1992, Statistical methods in water resources: Amsterdam, Netherlands, Elsevier, p. 522.
Hess, C.T., Korash, J.K., and Einloth, C.J., 1987, Radon in houses due to radon in potable water, in Hopke, P.K., ed, Radon and its decay products: Occurrence Properties and Health Effects, American Chemical Society Symposium Series 331, American Chemical Society, Washington, D.C., p. $30-41$.

Johnson, G.C., Zimmerman, T.M., Lindsey, B.D., and Gross, E.L., 2011, Factors affecting groundwater quality in the Valley and Ridge aquifers, eastern United States, 1993-2002: U.S. Geological Survey Scientific Investigations Report 2011-5115, 70 p.

Kucks, R.P., 2005, Terrestrial radioactivity and gamma-ray exposure in the United States and Canada: gridded geographic images: U.S. Geological Survey, digital data, accessed July 9, 2012, at http://pubs.usgs.gov/of/2005/1413/ datafiles.htm.

Lindsey, B.D., and Ator, S.W., 1996, Radon in ground water of the Lower Susquehanna and Potomac River Basins: U.S. Geological Survey Water-Resources Investigations Report 96-4156, $6 \mathrm{p}$.

Low, D.J., Hippe, D.J., and Yannacci, D., 2002, Geohydrology of southeastern Pennsylvania: U.S. Geological Survey Water-Resources Investigation Report 00-4166, 347 p.

Miles, J., 1998, Mapping radon-prone areas by lognormal modeling of house radon data: Health Physics, v. 74, p. $370-378$.

Miles, C. E., and Whitfield, T. G., comps., 2001, Bedrock geology of Pennsylvania: Pennsylvania Geological Survey, 4th ser., dataset, scale 1:250,000. [Available online as a ZIP file.]

Milry, Paul, and Cothern, C.R., 1990, Scientific background for development of regulations for radionuclides in drinking water, in Cothern, C.R., and Rebers, P.A., eds., Radon, radium, and uranium in drinking water: Chelsea, Mich., Lewis Publishers, 16 p.

National Research Council, 1999, Risk assessment of radon in drinking water: Washington, D.C., National Academy Press, 279 p.

Noether, G., 1971, Introduction to statistics: Boston, Mass., Houghton Mifflin Company, p. 169-170.

Pennsylvania Department of Environmental Protection, 2013, Public Water Supplier's (PWS) service areas: Pennsylvania Department of Environmental Protection, digital data, accessed December 6, 2013, at http://www.pasda.psu.edu/ data/dep/historic/PublicWaterSupply/.

Pennsylvania Geological Survey, 2008, Physiographic Provinces: Pennsylvania Geological Survey, digital data, accessed January 25, 2012, at http:/www.pasda.psu.edu. 
Pirc, S., and Rose, A.W., 1981, Uranium anomalies in paleoaquifers near sandstone-type uranium deposits in the Devonian Catskill Formation of Pennsylvania, in Rose, A.W., and Gundlach, H., eds., Geochemical Exploration: Journal of Geochemical Exploration, v. 15, p. 219-231.

Prichard, H.M., 1987, The transfer of radon from domestic water to indoor air: Journal of American Water Works Association, v. 79, no. 4., p. 159-161.

Razali, N.M., and Wah, Y.B., 2011, Power comparisons of Shapiro-Wilk, Kolmogorov-Smirnov, Lilliefors and Anderson-Darling tests: Journal of Statistical Modeling and Analytics, v. 2, no. 1, p. 21-33.

Senior, L.A., 1998, Radon-222 in the ground water of Chester County, Pennsylvania: U.S. Geological Survey WaterResources Investigations Report 98-4169, 32 p.

Senior, L.A., 2009, Groundwater-quality assessment, Pike County, Pennsylvania, 2007: U.S. Geological Survey Scientific Investigations Report 2009-5129, 53 p.

Senior, L.A., 2014, A reconnaissance spatial and temporal assessment of methane and inorganic constituents in groundwater in bedrock aquifers, Pike County, Pennsylvania, 2012-13: U.S. Geological Survey Scientific Investigations Report 2014-5117, 91 p., http://dx.doi.org/10.3133/ sir20145117.

Senior, L.A., Cravotta, C.A., III, and Sloto, R.A., 2016, Baseline assessment of groundwater quality in Wayne County, Pennsylvania, 2014: U.S. Geological Survey Scientific Investigations Report 2016-5073, 136 p., http://dx.doi. org/10.3133/sir20165073.

Senior, L.A., and Vogel, K.L., 1995, Radium and radon in ground water in the Chickies Quartzite, southeastern Pennsylvania: U.S. Geological Survey Water-Resources Investigations Report 92-4088, 145 p.

Sevon, W.D., 1975, Geology and mineral resources of the Tobyhanna and Buck Hill Falls quadrangles, Monroe County, Pennsylvania: Pennsylvania Geological Survey, 4th series, Atlas 204ab, 2 pls.

Sloto, R.A., 2000, Naturally occurring radionuclides in the ground water of southeastern Pennsylvania: U.S. Geological Survey Fact Sheet 012-00, 8 p..

Sloto, R.A., 2013, Baseline groundwater quality from 20 domestic wells in Sullivan County, Pennsylvania, 2012: U.S. Geological Survey Scientific Investigations Report 2013-5085, 27 p., http://pubs.usgs.gov/sir/2013/5085/.

Sloto, R.A., 2014, Baseline groundwater quality from 34 wells in Wayne County, Pennsylvania, 2011 and 2013: U.S. Geological Survey Open-File Report 2014-1116, 24 p., http:// dx.doi.org/10.3133/ofr20141116.
Turner-Peterson, C.E., 1988, A comparison of uranium-bearing sequences in the Newark Basin, Pennsylvania and New Jersey, and the San Juan Basin, New Mexico, in Foehlich, A.J., and Robinson, G.R. Jr., eds., Studies of the early Mesozoic Basins of the Eastern United States: U.S. Geological Survey Bulletin 1776, p. 350-356.

U.S. Bureau of the Census, 2000, 2000 county \& county equivalent areas: U.S. Bureau of the Census, digital data, accessed June 11, 2008, at https://www.census.gov/geo/ maps-data/data/cbf/cbf_counties.html.

U.S. Bureau of the Census, 2010a, DP-1 profile of general population and housing characteristics: U.S. Bureau of the Census, table, accessed June 20, 2012, at http://factfinder2. census.gov/.

U.S. Bureau of the Census, 2010b, U.S. Census TIGER/Line ${ }^{\circledR}$ Shapefiles -Tabulated blocks: U.S. Bureau of the Census, digital data, accessed February 7, 2013, at ftp://ftp2.census. gov/geo/tiger/TIGER2010BLKPOPHU/.

U.S. Environmental Protection Agency, 1992, Consumers Guide to Radon Reduction-How to reduce radon levels in your home: U.S. Environmental Protection Agency EPA 402-k92-003, $17 \mathrm{p}$.

U.S. Environmental Protection Agency, 2011, Why is radon the public health risk that it is?, accessed November 1, 2011, at http://www.epa.gov/radon/aboutus.html.

U.S. Environmental Protection Agency, 2012, A citizen's guide to radon: U.S. Environmental Protection Agency, Indoor Environments Division, EPA402/K-12/002, 16 p., accessed June 13, 2013, at http://www.epa.gov/radon/pubs/ citguide.html.

U.S. Geological Survey, 2016, USGS water data for Pennsylvania, accessed May 6, 2016, at http://waterdata.usgs.gov/ $\mathrm{pa} /$ nwis/nwis.

Vinson, D.S., Campbell, T.R., and Vengosh, Avner, 2008, Radon transfer from groundwater used in showers to indoor air: Applied Geochemistry, v. 23, p. 2678-2685.

Wanty, R.B., Lawrence, E.P., and Gunderson, L.C.S., 1992, A theoretical model for the flux of radon from rock to ground water: Geological Society America Special Paper 271, p. $73-78$.

Wedepohl, K.H., 1995, The composition of the continental crust: Geochimica et Cosmochimica Acta, v. 59, p. $1217-1239$.

World Health Organization, 2009, WHO handbook on indoor radon, a public health perspective: Geneva, Switzerland, World Health Organization, 95 p. 
Publishing support provided by the

U.S. Geological Survey Science Publishing Network,

West Trenton Publishing Service Center

For more information concerning the research in this report, contact:

Director, Pennsylvania Water Science Center

U.S. Geological Survey

215 Limekiln Road

New Cumberland, PA 17070

http://pa.water.usgs.gov/ 


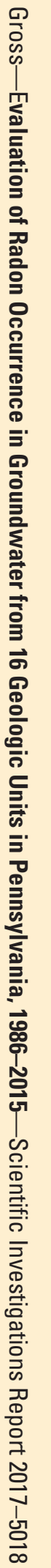

